Kolarctic CBC

EU FINLAND NORWAY RUSSIA SWEDEN

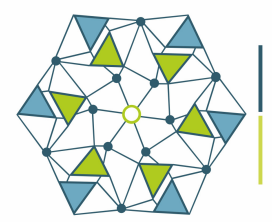

K5ᄃ

RAS
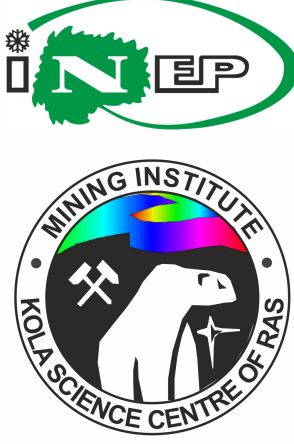

PROCESSING OF CUT-OFF GRADE ORES

AND COPPER AND NICKEL INDUSTRY

PROCESS WASTE: A FEASIBILITY STUDY 

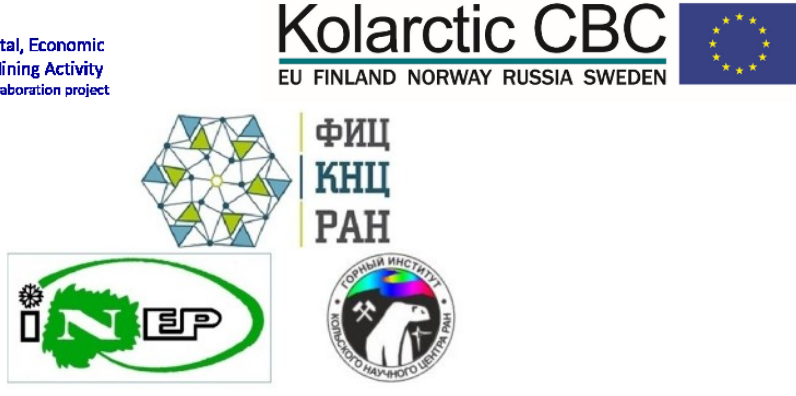

\section{PROCESSING OF CUT-OFF GRADE ORES AND COPPER AND NICKEL INDUSTRY PROCESS WASTE: A FEASIBILITY STUDY}

Svetlov A.V., Krasavtseva E.A., Goryachev A.A., Masloboev V.A., Mitrofanova G.V., Chernousenko E.V., Neradovsky Yu.N., Kameneva Yu.S., Vishnyakova I.N. 


\section{Processing of Cut-Off Grade Ores and Copper and Nickel Industry Process Waste:} A Feasibility Study / A. V. Svetlov et al. — Apatity: FRC KSC RAS, 2020. — 53 p.

ISBN 978-5-91137-424-2

The processing of previously unclaimed ores and wastes as sources of nonferrous metals, with an associated reduction in the environmental burden, is a promising field of research. Besides, many relatively minor non-ferrous metal deposits with complex mining engineering and geological properties exist, whose development by conventional mining methods is not economically feasible. The theoretical possibility of processing the cut-off grade copper-nickel objects of Murmansk Region was shown. Process conditions were found making the process economically feasible. Processing these mineral feed types will also allow in the long term to improve the environmental situation in the region.

Keywords: low-grade copper-nickel ores, acid mine discharge, copper-nickel ore concentration tailings, granulated slag, recovery of non-ferrous metals by flotation, heap leaching methods.

This research was conducted with the financial support of the Kolarctic CBC 2014-2020 programme, Project no KO1030 Supporting Environmental, Economic and Social Impacts of Mining Operations.

Научное издание

Технический редактор В.Ю. Жиганов

Подписано к печати 28.05.2020. Формат бумаги 60×84 1/16.

Усл. печ. л. 3,08. Заказ № 17. Тираж 300 экз.

ФГБУН ФИЦ КНЦ РАН

184209, г. Апатиты, Мурманская область, ул. Ферсмана, 14

ISBN 978-5-91137-424-2

(C) Svetlov A.V., Krasavtseva E.A., Goryachev A.A., Masloboev V.A., Mitrofanova G.V., Chernousenko E.V., Neradovsky Yu.N., Kameneva Yu.S., Vishnyakova I.N., 2020

(C) Institute of North Industrial Ecology Problems, 2020

(C) Federal Research Centre "Kola Science Centre of the Russian Academy of Sciences", 2020 


\section{Introduction}

The Russian Federation holds mineral resources that are unique in terms of both grade and quantity, which allows the Russian economy to cover its demand for minerals and secure itself a stable geopolitical position [1]. At the same time, the Russian mineral industry is mainly composed of long-standing operations. The high resource consumption and energy intensity of the mining industry is a major obstacle to its technological modernization or reconstruction.

As a result, negative environmental impacts of the mining industry have become persistent in mining regions. With the existing environmental protection mechanisms, neither prevention of or compensation for such impacts is technically or economically feasible.

Moreover, a deterioration of ore grades, a reduction in proven mineral reserves, and major complication in the industrial development of the mineral resources are expected. The geography of Russia;s mineral resources is remarkable, since a major part of commercial deposits is located in the Russian Arctic [2]. Process waste includes stored overburden and host rocks, cut-off grade ores, concentration tailings, coal, ferrous and non-ferrous metals industry waste, and construction materials industry waste. In the Russian Federation, more than 300 thousand ha of land surface is occupied by process waste, about 100 billion tons of waste is accumulated in dumps and tailing storage facilities [3, 4].

In Murmansk Region alone, more than 200 million tons of mining waste is stockpiled annually [5]. The management and maintenance of dumps, overburden, slags, tailings and sludge storages facilities involves significant costs. The dusting of dumps and tailings, the leaching of reagents and heavy metals into natural surface and groundwater negatively affects natural ecosystems and human health, which is especially pronounced in areas with extreme climatic conditions [6].

The commercial interest in the sulfide-containing waste of the mining and metals industry is based, on the one hand, on its environmental hazard, which manifests itself in the disturbance and degradation of ecosystems. On the other hand, in the mining and concentration process of non-ferrous ores, about $25 \%$ of nickel and $15 \%$ of copper, $40 \%$ of cobalt, $25 \%$ of zinc, $15 \%$ of molybdenum and lead is lost. In the process of waste storage, the sulfides of non-ferrous metals and iron are oxidized with the formation of sulfuric acid, while heavy metals pass into water-soluble salts [7-11]. Hypergenic changes in the minerals of the process waste occur much faster than in a natural geological setting. This intensification is facilitated by the activation of the mineral surfaces during their grinding.

The development for new processes using combinations of concentration and hydrometallurgical methods is the most important direction of both theoretical and applied research [12]. An urgent research task is to develop physicochemical 
processes supporting improved recovery of valuable components from low-grade ores, as well as mining and concentration waste [13-16].

\section{A review of the existing processing methods of low-grade copper-nickel ores and copper-nickel concentration waste.}

\subsection{Processing of low-grade copper-nickel ores.}

The processing of waste and previously unclaimed ores as sources of non-ferrous metals, with an associated reduction in the environmental burden, is a promising field of research. Besides, many relatively minor non-ferrous metal deposits with complex mining engineering and geological properties exist, whose development by conventional mining methods is not economically feasible. Such deposits are characterized by increased oxidation of ore minerals, low grade, refractory ores, etc. [14, 17-19].

Scientific and process engineering studies on the industrial processing of lowgrade ores and anthropogenic deposits (AD) are mainly associated with the development of new, non-conventional technology [20-26], which requires a detailed study using state-of-the-art methods of modifying the material composition of concentration products, physico-chemical mineral surface properties, involving modeling methods at the stage of the process flow development.

When assessing the feasibility of processing ADs, teh following has to be predicted and considered:

- hypergenic processes occurring in the mining waste and leading to the leaching of toxic elements, heavy metals, and flotation reagents into the environment, generating acid mine discharge (AMD),

- changes in the process properties of the potentially recoverable minerals in the mining wastes,

- the possibilities of intensifying hydrometallurgical processing of low-grade mineral feeds of natural and anthropogenic origin.

For a number of years, studies aimed at developing efficient concentration processes for low-grade and cut-off grade copper-nickel ores were conducted at the Mining Institute of the Kola Research Center at the Russian Academy of Sciences (KRC RAS) [27, 28]. The possibility of using gravitational, radiometric, and magnetic separation methods in preconcentration was studied. It was shown that in finely disseminated copper-nickel ores, the application of radiometric and magnetic methods is not justified. The studies showed the prospects of using a combination of ore preconcentration circuits to obtain one or more process types of commercial ore for subsequent concentration or processing. This approach was used in the development of concentration processes for the anthropogenic ores in the Allarechensk mining waste dumps (hereinafter the Allarechensk anthropogenic deposit, or Allarechensk AD) and the cut-off grade ores of the Pechenga ore field. 
The methods used made it possible to obtain tailings and a concentrate suitable for further processing.

\subsection{Processing of copper-nickel ore concentration tailings.}

A review of the existing methods for the further recovery of metals from fresh and mature concentrator tailings in Russia and other countries is presented in a paper by Rudnev [29]. It is noted that for the processing of concentration tailings, the most widely used methods include the repulping of mature tailings followed by flotation, classification of fresh tailings, leaching of copper, flotation of sludge, classification with regrinding of the sand fraction with subsequent flotation, gravity concentration, magnetic separation, separation of gold by cyanides with carbon sorption (the carbon-in-pulp process). Thus, flotation, hydrometallurgical, and combined flotation and hydrometallurgical methods may perform well in the processing of tailings.

The paper [30] provides a physical justification for the possibility of separating mineral particles by density and size at the disposal stage during the hydrotransport of final tailings. It is shown that the product isolated from the bottom of the pressure tailings pipe at the Almalyk Copper Concentrator had a three times higher copper and gold grade compared to the tailings. Similar preconcentration methods to recover valuable components from tailings can be used for the subsequent processing of industrial process products.

A promising innovative method for the processing of copper-zinc ore concentration tailings based on the selective flocculation of fine particles with the subsequent flotation of the resulting floccules or their deposition was proposed at IPKON RAS. The process conditions for the selective flocculation of non-ferrous metal sulfides were formulated, consisting in the use of hydrophobicity, either natural or acquired through the addition of collectors, for the aggregation of particles by a hydrophobic polymer. Various processing flows were proposed for the concentration tailings of copper-zinc ores [31]. One of the processes includes the bulk selective flotation of sulfides from the sand fraction of the tailings after activation in a turbomill. Another process is based on direct selective flotation. The tailings slurry fraction is processed either by selective sulfide flocculation and floccule flotation followed by the hydrometallurgical processing of secondary tailings, or in a hydrometallurgical process based on acid leaching preceded by mechanochemical activation and followed by the staged sorption of metals from solutions using modified zeolites. After mechanochemical activation, the mature tailings of the Urup Concentrator were processed by flotation into a commercial pyrite concentrate, the Barsuchiy Log copper-zinc ore concentration tailings into a pyrite concentrate and zinc by-product, while the tailings of the Buribayevski Concentrator were in a single flotation circuit processed into a copper-zinc concentrate with a grade close to that of the run-of-mine ore. 
Research by the GINTsVETMET Institute showed that both fresh and mature tailings can be processed into a high-grade pyrite concentrate, a copper-zinc product for hydrometallurgical processing, and a quartz product suitable as a raw material in the construction industry, manufacture of filling mixtures, and metallurgical fluxes.

Tailings are being processed on a global scale due to the depletion of commercial ore reserves. Copper recovery plants fed with fresh tailings are operated at existing concentrators in the US, Philippines, Zaire, Australia [32].

\subsection{Copper-nickel slag management practices.}

Particular attention is paid globally to the development of processing technology for non-ferrous metal slags [33-36 etc.]. At the forefront of this effort are the United States, Britain, and Japan. The general approach can be described as follows: when the slag is ground to a particle size of $90 \%$ passing $-0.063 \mathrm{~mm}$, copper recovery increases to $70 \%$, and leaching the slag with ammonia solutions performs best. At the Mount Morgan operation, reverberatory furnace slag is processed to recover copper and gold in a process that includes two-stage crushing to a particle size of $-8 \mathrm{~mm}$, two-stage grinding, and flotation at $\mathrm{pH}=6.8-7.5$. After a cleaner flotation, the concentrate has a copper grade of $20 \%$ at a recovery of $80 \%$ of copper and $94 \%$ of gold [32].

Concentrators in Russia's Ural region also have considerable experience in this field [37]. Non-ferrous slag is processed, for example, at Sredneuralsky Copper Smelter. After grinding and classification, the slag undergoes flotation. The resulting copper concentrate with a solids content of $50-60 \%$ and a copper grade of $10 \%$ to $25 \%$ is fed to the copper smelter's batching plant [38]. Sibay branch of Uchalinsky GOK is an illustration of the flotation possibilities of various types of copper slag using circulating, process, and tailings effluent water. The differences in the material composition of the slag types generated at this operation are discussed. Findings are presented that show the effect of the composition and properties of the aqueous phase on the copper recovery performance. For instance, in the flotation of fayalite-ferrite slag when using circulating water at $\mathrm{pH}=11$, copper recovery into the concentrate was $90 \%$; when using process water at $\mathrm{pH}=7.9$, copper recovery was $88 \%$, and $87 \%$ when using tailings effluent at $\mathrm{pH}=5.5$. Copper recovery was the lowest at $36 \%$ when dumped fayalite-magnetite-pyrite slag was floated in process water at $\mathrm{pH}=7.9$ [39].

The possibilities of using dump granular slag of copper-nickel operations, mainly for the production of building materials, have been examined in a number of papers [40-42, etc.].

The results of long-term studies of the viscosity of metallurgical copper-nickel slags (electric furnace and cobalt slags of the Severonickel smelter) are presented in the monograph by Rossinsky [43]. The critical importance of the viscosity value on the recovery of non-ferrous metals in the smelting of copper-nickel ores was shown. 
The implementation at the Severonickel mineral wool operation of the Kola MMC of the control station software making it possible to determine the amount of corrective additives used and the average composition of the corrected slag melt and evaluate the economic performance of certain MMC wastes as corrective additives, improved the quality of the produced mineral wool plates [44]. The average fiber diameter decreased by $80 \%$, the number of non-fibrous inclusions by $20 \%$, thermal conductivity by $5 \%$. Fiber length and elasticity increased.

In [45], a method is proposed for the sorption treatment of the bulk effluents of non-ferrous metal operations to remove $\mathrm{Ni}, \mathrm{Cu}, \mathrm{Co}$ cations. Based on the hardening mineral dispersion process, an inexpensive effective sorbent has been developed using slags formed as a result of ore-thermal processing of sulfide copper-nickel ores. The optimal synthesis conditions have been identified, and the phase composition of the reaction products and the sorption mechanism are described. A method for the disposal of spent sorbents containing up to 5.0-5.5 wt $\%$ non-ferrous metals $(\mathrm{Ni}, \mathrm{Cu}, \mathrm{Co})$ is proposed - reusing as raw materials in ore-thermal furnaces.

In [46, 47], a 20\% hydrochloric acid solution was used to recover non-ferrous metals from the slag of the Pechenganickel Smelter: the S:L ratio was 1:4, the process temperature was $50-80^{\circ} \mathrm{C}$, and the leaching time was 3-5 hours. The slag was ground to a particle size of $-0.063+0.050 \mathrm{~mm}$. A range of feed intervals was used. The recovery of the key components into the solution, depending on the leaching regime, was, \%: $\mathrm{Fe}-81-93 ; \mathrm{Cu}-$ 91-96; Ni - 89-94; Co - 91-99; Mg-94-99.

\subsection{Processing of natural and anthropogenic mineral feeds by leaching.}

For the processing of low-grade natural and anthropogenic mineral feeds, underground and heap leaching methods (physicochemical geoengineering technologies) are considered promising. The hydrometallurgical recovery of nonferrous metals by underground, heap, and tank leaching is based on the same reactions between the ore minerals and the solvent (sulfate solutions). The first process step is to make the metals pass into solution, then the suspension is removed by sedimentation and the solution is fed for the recovery of metals by precipitation, extraction, or electrolysis. Further, the solution, after the appropriate adjustment of its chemistry, is recycled for leaching or discharged into the sedimentation pond [14]. In recent decades, these types of industrial processes have been intensified through the use of microbiological oxidation of sulfide minerals. Physical and chemical geoengineering technologies for the recovery of copper, uranium, and gold are most commonly used on a large scale. Underground leaching of copper ore as a natural process is observed in most pyrite deposits. As a result of the circulation of mine water through cracks in the ore and rock, the oxidation and dissolution of pyrite and copper sulfides occur. Leaching is especially intensive during spontaneous fire events. Heap and underground leaching of copper ore is presently 
used at dozens operations globally producing up to several hundred thousand tons of copper per year (in the US, more than 300 thousand tons) [48].

Bio-leaching is a relatively recent method in the global recovery practice, compared with heap leaching. Experimental work was carried out in the USSR, but its results have never been commercialized in the industry. For example, in 1964, a pilot underground copper leaching plant using bacterial regeneration of solutions was put into operation at the Degtyarsky mine in Russia's Ural region [49]. However, it should be noted that to date, none of the leaching methods has become part of the conventional mining process [14]. Russian industry has developments in this area and is actively exploring the global leaders' experience with all types of leaching. However, there are a number of practical technological challenges. As a rule, this is due to a combination of factors: remote location of operations, poor or absent infrastructure, challenging climatic conditions, and the material composition of the waste [50-53].

The world's hydrometallurgical experience proves perceptiveness of the heap leaching method mainly for recovery of gold, copper and uranium, from low-grade ores, mining and processing waste $[14,15,54-60]$. About $20 \%$ of the world's copper production is accomplished by heap leaching of ores from mines and processing plants as well as waste ores from dumps and further processing by solvent extraction and electrowinning (SX/EW) [15].

Biological leaching was proved to be efficient for sulfides of $\mathrm{Co}, \mathrm{Ga}, \mathrm{Mo}, \mathrm{Ni}, \mathrm{Zn}$ and $\mathrm{Pb}$ [15]. Sulfide minerals including metals of the platinum group (Pt, $\mathrm{Rh}, \mathrm{Ru}$, $\mathrm{Pd}$, Os and Ir) can be also subjected to preprocessing with microorganisms [61]. In recent decade, pilot tests on heap leaching of low-grade copper and nickel sulfide ores were launched (the mines involved are Radio Hill in the Western Australia; Talvivaara, Sotkamo in Finland; Khami, Sintszyan in PRC) [62-70].

The world industry has accumulated scientific and production experience related to assessment of ore amenability to heap leaching, engineering and design of heap leach pads, solution irrigation systems, and collection of pregnant solutions, heap leaching schemes optimization, and chemicals regeneration [14, 54, 71]. Mathematical modeling techniques are being developed [72-75].

When using heap leaching, ore grades can be significantly lower than in the conventional metallurgical technologies. For example, for the heap leaching process used by the Finnish Company "Talvivaara Mining Company Plc" at its nickel mine situated in the subarctic zone of the north-east of Finland, average nickel grade amounts to $0.27 \%$, copper $0.14 \%$, cobalt $0.02 \%$, zinc $0.56 \%$ [76]. In cases of technogenic waste processing, the standard ore grade can be even lower. This can be explained by the fact that ore mining costs have been already spent, and transport expenses are allocated to the remediation budget [50]. 
The Russian Federation has all necessary conditions for a wide use of the heap leaching method for metal recovery. Undoubtedly, certain complications may result from unfavorable climate in the mining and processing regions of Russia. Most of foreign mines are situated in the regions with warm climate, where the lowest temperature is above zero even in cold seasons. Therefore, it should be considered the specifics of the heap leaching process implementation in the regions with arctic and subarctic climate.

Currently, there are more than 300 heap leaching facilities in the world. About 70 of them (about $25 \%$ ) are operated in the regions with arctic and subarctic climate with subzero average annual temperatures. These mines are located in North Europe, Asia, North America, as well as in the Andean regions of South America. Leading companies in the Arctic area are gold mines. They include Kinross Fort Knox Gold mine (Fairbanks, Alaska), Eagle and Coffee-Gold (Yukon Territory, Canada), as well as Casino Project (Yukon Territory, Canada) processing sulfide and oxidized copper ores bearing gold [77].

Low temperature and permafrost complicate implementation and operation of heap leaching pads and increase their costs. The following measures are taken to keep the leaching heaps warm $[58,78,79]$ :

- $\quad$ construction of ore stacks in cells;

- $\quad$ use of drip emitters irrigation system consisting of pressure emitter trickles of labyrinth type;

- $\quad$ use of snow cover as a natural thermal insulation layer over a dump;

- freezing of "ice glaze" on a heap surface;

- covering a heap with thermally insulating materials during a cold season (polymer geo-textiles, polyethlene films with heated air supply underneath a covering mining material, with a layer thickness of up to $1 \mathrm{~m}$ );

- heating of process solutions.

In addition to these measures, a heap leach pad should be located in a place ensuring maximum possible use of solar energy and minimum wind impact. A pad should not be built on permafrost soil, and frozen ore should not be placed on a dump as well.

Russian specialists have developed the method for precious metals leaching from mineral raw materials at low temperature (down to $-40{ }^{\circ} \mathrm{C}$ ), without any need for solvent percolation through ore lumps [58]. This method was called a "passive leaching". In brief, the method includes the following steps: ore is crushed, then it is mixed with alkaline cyanide solution mixed to complete impregnation of the ore mass, then it is held for some time, until all free gold transfers into a water-soluble state. On completing the process, the ore mass is subjected to water leaching by one of the two methods depending on technical and economic calculations: directly in heaps and dumps in-situ; or based on a counterflow scheme in any flushing apparatus. The main feature of the passive leaching method is its 
applicability in severe cold conditions for gold and silver raw material processing. This is important for the Far North regions.

Quite a wide range of specialists used to think that geotechnologies, i.e. leaching in heaps, dumps, sludge storage facilities is unreasonable and unrealistic in cold climates with subzero average annual temperatures, permafrost soils, short warm period (three months a year). However, yet in the eighties of the $20^{\text {th }}$ century, processing parameters and indicators of percolation (heap) and passive leaching were studied and determined, based on the ores from 12 deposits and material of two gold-processing plants in Yakutia and Magadan region, Russia. Those parameters included: water retention capacity of gold- and silver-bearing materials, absorption of chemical agents, optimum solvent concentration, temperature impact, metal recovery [58]. For the first time, the experiments proved that gold and silver minerals can be transferred into a water-soluble form by addition of cyanides under the temperature range from 0 down to $-40{ }^{\circ} \mathrm{C}$.

After many years of cryomineralogenesis studies in mining and technogenic massifs, Ptitsyn developed a geochemical basis for metal geotechnology in the permafrost environment. Analysis of copper ore samples from the Udokan deposit experimentally showed conditions of copper solutions formation and migration under subzero temperatures $[80,81]$. Corrosive solution originates at the contact between sulfide ores and atmosphere. By reacting with ores during gravity migration, it forms an oxidation zone. The solutions penetrate into ice intergranular space, and between ice and minerals contacts. Cryogenic zones should be considered as a common feature in the areas of permafrost development [81, 82].

The most important factors of cryomineralogenesis in mining and technogenic massifs are the following [83]:

- $\quad$ wide development of film water;

- $\quad$ exothermic effect of sulfides oxidation;

- $\quad$ significant impact of psychrophilic bacteria, including understudied silicate bacterium and other simple organisms;

- $\quad$ cryogenic solutions formation and migration conditions;

- low freezing temperature of high-concentrated percolated solutions, mainly sulfate ones;

- multiple geochemical barriers causing and ensuring mineralization;

- long-term existence of tectonic activity zones, which are conductors of both active endogenous fluid streams and exogenous supergenesis agents;

- frequency of changes in thermal conditions with various duration and intensity.

Ptitsyn's monograph describes an essential opportunity for using geotechnology for recovery of non-ferrous, rare and precious metals in permafrost areas with cold climate [80]. Metals transition into a liquid form is achieved by combined treatment of ores with film-type solutions and solutions produced by cryogenic concentration. 
An additional factor intensifying a heap leaching process is frost cracking, which increases contact surface between ore and solution. Due to gravity migration through rock conglomerated by ice, a concentrated freeze-resistant metal-containing solution can be accumulated on a waterproof foundation in the lower part of a massif. It ensures a possibility for the metal extraction and processing. The author pointed out that silting of massif could be reduced considerably during leaching at subzero temperatures.

Ptitsyn recommends using geotechnology methods at subzero temperatures for leaching gold, silver, copper, beryllium, magnesium, mercury, tin, bismuth, molybdenum, tungsten, manganese, nickel, as well as a number of rare metals found in significant quantity in highly-mineralized solutions [80]. The author assumed that lead, zinc, cobalt and platinum group metals can be recovered with the same method. Depending on ore composition, both acid (sulfate, chloride) and alkali (carbonate, ammonium, etc.) solutions can be used for leaching.

Nitrogen oxygen compounds are likely to be oxidizing substances for oxidized leach cap, but they need further studies [82, 84-87]. For example, nitrous acid activates various oxidizing processes including leaching of galena $(\mathrm{PbS})$, pyrites $\left(\mathrm{FeS}_{2}\right)$, pyrrhotite $\left(\mathrm{Fe}_{1-\mathrm{x}} \mathrm{S}\right)$, sphalerite $(\mathrm{ZnS})$ and chalcocite $\left(\mathrm{Cu}_{2} \mathrm{~S}\right)$ in sulfuric acid solutions [82]. The activating effect of $\mathrm{HNO}_{2}$ is intensified with its concentration increase, and is limited only by disproportion of $\mathrm{HNO}_{2}$ at the positive temperature range and low $\mathrm{pH}$ values. The experiments proved that nitrous acid stability under cryogenic conditions increases significantly even in highly acidic medium. Frost weathering modeling on the samples of copper-sulfide ores from the Udokan deposits showed that copper-sulfide oxidation accelerated considerably with nitrous acid addition, and has practically the same intensity throughout the analyzed range of parameters. The experiment involved leaching of fraction $0.063-0.2 \mathrm{~mm} 0.5 \mathrm{M}$ sulfuric acid solution, using $0.1 \mathrm{M}$ of nitrous acid and without it, at the temperatures of -20 and +20 ${ }^{\circ} \mathrm{C}$, at $\mathrm{S}: \mathrm{L}$ ratio of 1:5. The activating effect of $\mathrm{HNO}_{2}$ appears to a greater degree during freezing. Copper recovery from solid phase increases by 2.7 times at a room temperature, and by 4.7 times under cryogenic conditions [85].

Passive leaching of gold and silver raw materials, as well as justification of metals transition into a liquid phase with new oxidizing agents under subzero temperatures need generalization and experimental proofs for using it for sulfide ores and mine wastes processing.

In the next sections, the authors describe case studies and perspective of nonferrous metals recovery from sulfide and mixed ores with heap leaching in the northern regions of Russian Federation and abroad.

The Udokan deposit (in the North of Zabaykalsky Krai, Russia) is one of the largest copper deposits in the world, which is located 30 kilometers to the south from the Novaya Chara railway station, on the mountain range Udokan. The territory of the deposit is associated with the Russian Far North. Continuous permafrost area extends with thickness 
from $65 \mathrm{~m}$ under water courses to $950 \mathrm{~m}$ under the watershed divide. Permafrost rock temperature is from -7 to $-8{ }^{\circ} \mathrm{C}$, the active layer thickness is about $1 \mathrm{~m}$. By 2020 , it is planned to build a mining and metallurgical complex with capacity of 474,000 tons of copper per year. In addition to that, they plan to extract $277 \mathrm{t}$ of silver per year, and to process additionally off-balance ores using heap leaching method [86, 87].

According to Khalezov, high-grade and amenable ores of the Udokan deposit should be processed with a traditional processing method, i.e. melting process [88]. Oxidized, sulfideoxidized and low-grade mixed ores should be processed using geotechnologies, i.e. heap leaching. Such ores should be dumped on specially arranged pads during mining. For this purpose, the corresponding ore classification process should be used. This process has already been used for a long time by a number of mining companies in Russia. Pyrometallurgical processing will be a source for sulfuric acid and heat to warm heap leaching solutions. Consequently, pyro- and hydrometallurgical methods are suggested for ore processing. This will ensure a technical and economic effect, and enables to increase raw material usage. Copper minerals content is as follows: $68.5 \%$ of malachite $\left(\mathrm{Cu}_{2} \mathrm{CO}_{3}(\mathrm{OH})_{2}\right)$ and brochantite $\left(\mathrm{Cu}_{4} \mathrm{SO}_{4}(\mathrm{OH})_{6}\right) ; 29.6 \%$ of chalcocite $\left(\mathrm{Cu}_{2} \mathrm{~S}\right)$, covellite $(\mathrm{CuS})$, bornite $\left(\mathrm{Cu}_{5} \mathrm{FeS}_{4}\right) ; 1.9 \%$ of chalcopyrite $\left(\mathrm{CuFeS}_{2}\right)$. The ore has a vein, finely disseminated mineralization. Rock-forming minerals include quartz, feldspar, sericite, they amount up to $90 \%$, and resistant to acid. This fact determines low consumption of sulfuric acid. If leaching at Udokan is carried out only during warm season (140 days per year), leaching of ore with below $400 \mathrm{~mm}$ grain size will take 5-7 years. In case of a year-around operation with solution heating, the leaching will take 2-3 years. The SX/EW process is considered to be the most suitable method for copper extraction. The technology with closed water circulation enables to recover accompanying elements from ores, including rare and noble metals [88]. Solid residues of ore processing can be used for land reclamation and in construction industry.

The Talvivaara deposit of polymetallic ores in Sotkamo, Finland, has become the most striking instance of heap bioleaching implementation for sulfide ores processing under the Far North conditions [89-93]. This deposit is considered to be one of the largest sulfide deposits in Europe situated in the geographical environment that closely resembles the Murmansk region in Russia.

Talvivaara black schist ore contains pyrrhotite $\left(\mathrm{Fe}_{1-\mathrm{x}} \mathrm{S}\right)$, pyrite $\left(\mathrm{FeS}_{2}\right)$, sphalerite $(\mathrm{ZnS})$, pentlandite $\left((\mathrm{Fe}, \mathrm{Ni})_{9} \mathrm{~S}_{8}\right)$, violarite $\left(\left(\mathrm{Fe}, \mathrm{Ni}_{3}\right)_{3} \mathrm{~S}_{4}\right)$, chalcopyrite $\left(\mathrm{CuFeS}_{2}\right)$ and graphite $(\mathrm{C})$. Nickel is distributed in the different sulfide minerals as follows: pentlandite $71 \%$, pyrrhotite $21 \%$ and pyrite $8 \%$. Cobalt is distributed in the following mineralogical phases: pentlandite $11 \%$, pyrrhotite $26 \%$ and pyrite $63 \%$. The total copper is concentrated in chalcopyrite and the total zinc in sphalerite. The main silica-containing phases are quartz, mica, anorthite and microcline [92]. Ore bioleaching in Talvivaara was studied during two decades: beginning from laboratory experiments in leaching columns, and up to construction of a pilot heap [89-93]. 
The selected mining method is a large-scale open pit mining. During processing, ore is crushed and screened in four stages to $80 \%$ passing $8 \mathrm{~mm}$ (figure 1). After primary crushing, ore is conveyed to a secondary crushing plant, where it is crushed and screened in three stages. All material bellow $10 \mathrm{~mm}$ reports to agglomeration in a rotating drum, where pregnant leach solution (PLS) is added to the ore in order to consolidate fine particles with coarser particles. This preconditioning step makes ore permeable to air and water for heap leaching. After agglomeration, ore is conveyed and stacked in piles from eight to ten meters height on the primary heap pad. After 13-14 months of bioleaching on the primary pad, the leached ore is reclaimed, conveyed and re-stacked onto the secondary heap pad, where it is leached further in order to recover metals from those parts of the primary heaps, which had poor contact with the leaching solution. During the recovery process metals are precipitated from the PLS using gaseous hydrogen sulfide and $\mathrm{pH}$ adjustment [93].

The primary heap is irrigated at a rate of $51 / \mathrm{m}^{2} \cdot \mathrm{h}$. The irrigation solution $\mathrm{pH}$ is adjusted to 1.7-2.0, and the solution is distributed evenly over the heap surface. PLS is collected with a drainage system and discharged to PLS collection ponds. About $10-20 \%$ of the solution is pumped to a metals recovery plant and the rest is recirculated to the heap (figure 1).

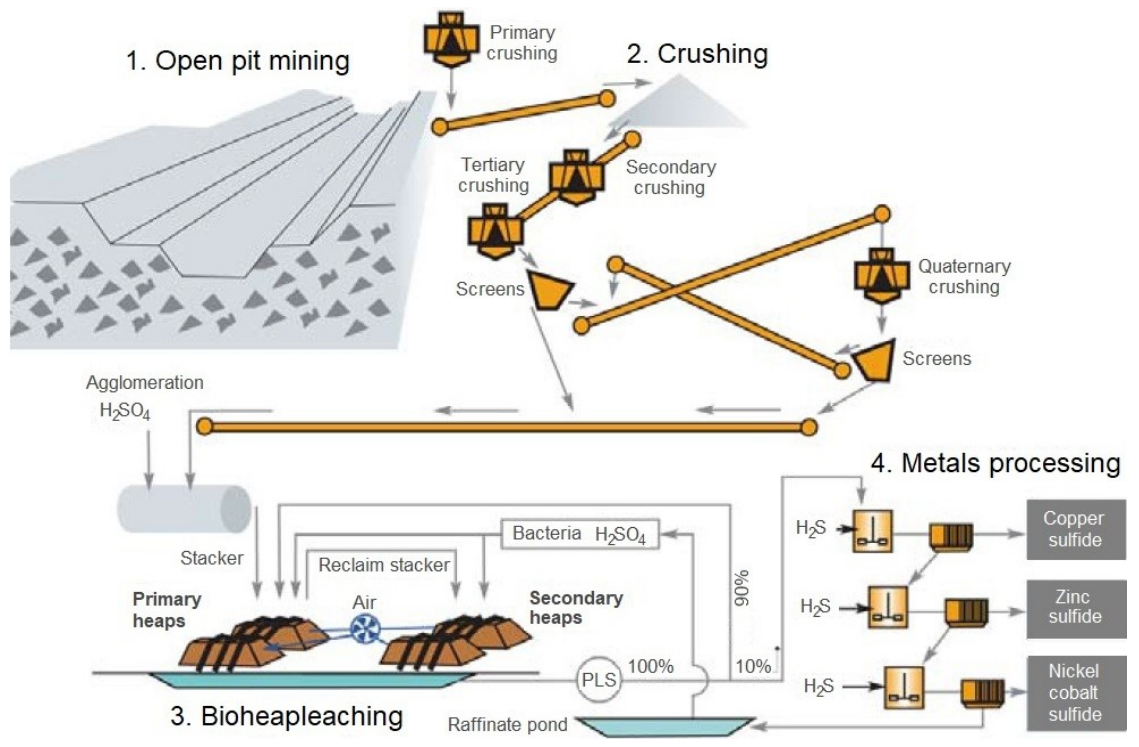

Figure 1. Process flow diagram of the "Talvivaara Mining Company Plc" [92]. 
The temperatures within the heap varied between $30-90{ }^{\circ} \mathrm{C}$, despite the climate, and PLS temperatures were $40-50{ }^{\circ} \mathrm{C}$ [89]. The microbial community in the heap (monitored by leachate analyses) varied during the first few months, becoming dominated by At. ferrooxidans and Desulfotomaculum geothermicum; other species identified were Thiomonas arsenivorans, Alicyclobacillus tolerans and Ferromicrobium acidophilum [91]. Analyses of ore samples from the heap revealed At. ferrooxidans, At. caldus and F. acidophilum. An uncultured bacterium clone $\mathrm{H} 70$ was found in both leachate and ore samples. Cell numbers varied between $10^{5}-10^{8}$ cells $/ \mathrm{mL}$ in leachate and between $10^{5}-10^{7}$ cells/g in ore. In 500 days, recoveries were Ni $92 \%$, Zn $82 \%$ Co $14 \%$ and $\mathrm{Cu} 2 \%$. The low copper recovery was explained by the minerals' electrochemical properties [16].

Talvivaara became the first commercial nickel sulfide heap leaching operation. Nickel production was launched in October 2008. It was originally planned to reach the design capacity $33.000 \mathrm{t}$ of nickel, $1.200 \mathrm{t}$ of cobalt, $60.000 \mathrm{t}$ of zinc and 10.000 $\mathrm{t}$ of copper by 2010 [16].. However, the peak performance was reached only by 2011 , and the parameters amounted only to the half of the planned figures $(16.087 \mathrm{t}$ of nickel) [94].

The project engineering and development at commercial scale occurred during the period, when non-ferrous metal prices were rather high [94]. In 2007, average annual price of refined nickel at London Metal Exchange increased by $52.5 \% \mathrm{USD} / \mathrm{t}$ in comparison with 2006 , i.e. from 24.416 to 37.230 . The perspectives of successful operation at commercial scale were attractive. However, during the following years, prices for non-ferrous metals (including nickel) dropped dramatically.

The tense situation in the world market led to bankruptcy of Talvavaara Mining Company Plc [94]. Regardless of the negative economic results, the company left a number of useful experiments, proved by experience, and having strategic value for further research and pilot tests:

- the microorganisms used in bioleaching process still exist and develop in the feed ore. They are endemic and well-adapted to the environment, what results in processing efficiency;

- $\quad$ high quality of materials recovered from solutions at commercial scale was demonstrated.

Early studies of hydrometallurgical methods for processing of copper-nickel ores from the Murmansk region deposits were launched in the 70 s of the previous century [20]. For referencing purposes, the main types of disseminated ores from the deposits Zhdanovsky, Kaula, Sopchinsky Plast and Lovnoozersky were selected. The metal content varied: $0.46-1.49 \% \mathrm{Ni}, 0.01-0.62 \% \mathrm{Cu}$. In the first experiments, the solution containing $150 \mathrm{~g} / \mathrm{l}$ of $\mathrm{H}_{2} \mathrm{SO}_{4}$ and $135 \mathrm{~g} / \mathrm{l}$ of $\mathrm{NaCl}$ was used as a leaching reagent. The laboratory and further large-scale tests proved the possibility of underground metal leaching from the Lovnoozersky deposit ores. 
The first data on a number of thionic bacteria in mine water of copper-nickel deposits in the Murmansk region are presented in the works of Lyalikova and Karavaiko et al. $[95,96]$. The possibility of their use for non-ferrous leaching was studied by Golovko et al. [20].

Currently, the research on justification of non-ferrous metal leaching from sulfide-containing natural and technogenic deposits of the Murmansk region continues $[26,51,97-100]$.

The technogenic deposit, the Allarechensk Deposit Dumps, is situated in the north-western part of the Murmansk region, $45 \mathrm{~km}$ to the south from the village Nickel, the Pechenga district. The deposit is a dump of mine waste formed after open-pit mining of the Allarechensk sulfide copper-nickel ore deposit, which was completed in 1971 [101].

The ores of the deposit are represented by two morphological types: massive ore containing the following valuable components: $5-18 \% \mathrm{Ni}, 0.15-8 \% \mathrm{Cu}$, up to $0.3 \%$ $\mathrm{Co}$; and disseminated ore containing $0.2-7.9 \% \mathrm{Ni}, 0.12-4.9 \% \mathrm{Cu}$, up to $0.12 \% \mathrm{Co}$; with grades ranging: from $7.9,4.9$, and $0.12 \%$ (for high-grade ores) and up to 0.2 , 0.12 and $0.008 \%$ (for low-grade ores), respectively. Ore studies enabled to define two key properties, which could be useful for ore processing: gravity and magnetic contrast $[97,98,101]$.

Industrial tests showed that magnetic separation enables to efficiently process both raw and high-grade ones within the size range of 5-60 $\mathrm{mm}$, and produce a highgrade concentrate with cumulative content of $\mathrm{Ni} 2.0-3.7 \%, \mathrm{Cu} 1.5-2.2 \%$ and $\mathrm{Co}$ $0.03-0.08 \%[97,98,101]$.

For processing of a fine fraction constituting $10-15 \%$ of all the deposit volume, it was studied the possibility of non-ferrous metal recovery using biotechnology. The deposit ores are amenable to bioleaching due to their structural and textural properties. The chain of sulfide leaching was determined: pyrrhotite $\left(\mathrm{Fe}_{1-\mathrm{x}} \mathrm{S}\right) \rightarrow$ pentlandite $(\mathrm{Fe}, \mathrm{Ni})_{9} \mathrm{~S}_{8} \rightarrow$ chalcopyrite $\left(\mathrm{CuFeS}_{2}\right)$, pyrite $\left(\mathrm{FeS}_{2}\right)$. The crystal structure, fracturing, substitution by violarite $\left((\mathrm{Fe}, \mathrm{Ni})_{3} \mathrm{~S}_{4}\right)$ and bravoite $\left((\mathrm{Fe}, \mathrm{Ni}, \mathrm{Co}) \mathrm{S}_{2}\right)$, contributing to faster mineral destructurization, encourage pentlandite $(\mathrm{Fe}, \mathrm{Ni})_{9} \mathrm{~S}_{8}$ leaching. A large portion of minerals has excessive sorption capacity and is characterized by ore mineral binding. These factors are referred to adversity $[97,98,101]$.

JSC Irgiredmet has performed large-scale laboratory tests and calculation of technical and economic parameters on applicability of non-ferrous bacteria heap leaching technology for magnetic separation products in the dumps. One of the analyzed process flow diagrams is presented in Figure $2[98,101]$.

Regardless of the fact that the resources of the deposit are not large and, according to various estimates, amount to about one million tons of ore containing on the average $0.54 \% \mathrm{Ni}$ and $0.47 \% \mathrm{Cu}$, the development of only explored reserves is considered to be a commercially viable investment project with low risks [98]. 


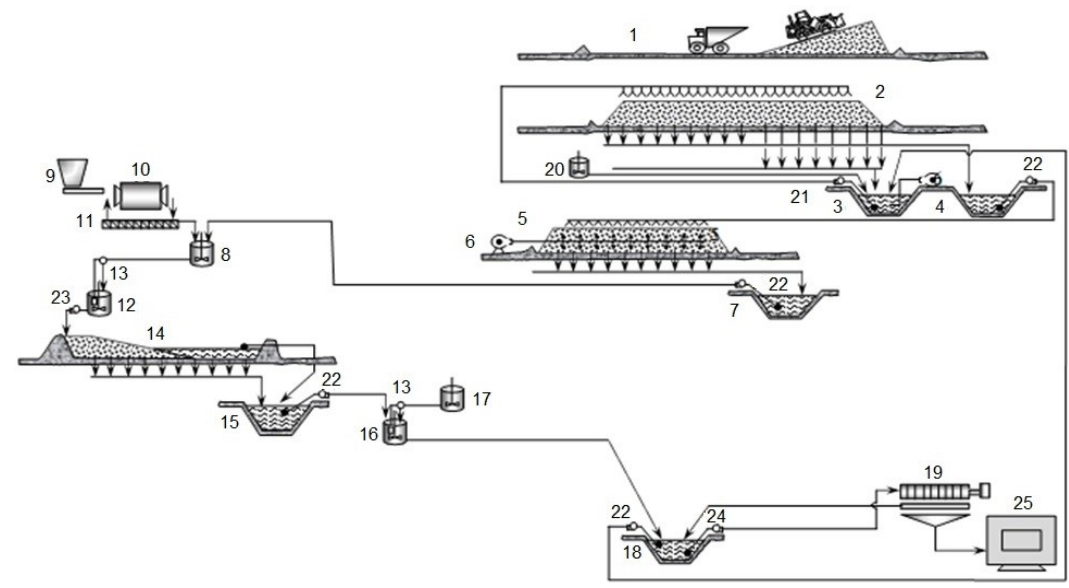

Figure 2. Process flow diagram of the ore heap leaching process at the Allarechensk Deposit Dumps [98]. 1 - heap at the forming stage; 2 - heap at the irrigation stage; 3 - raffinate pond; 4 - PLS pond; 5 - heap for iron oxidation; 6 - aeration system; 7 - oxidized PLS pond; 8 - neutralizing tank; 9 - crushed lime bunker; 10 - ball mill; 11 - spiral classifier; 12 - setting tank; 13 - automatic titration system; 14 - sludge storage; 15 - storage pond for neutralized PLS; 16 - precipitating tank; 17 - reagent tank; 18 - settling pond; 19 -filter-press; 20 - bacteria cultivation tank; 21-24 - pumps; 25 - furnace.

\section{Prospective processing targets in Murmansk Region.}

\subsection{Waste dumps of the Allarechensk copper-nickel deposit.}

The Allarechensk anthropogenic deposit is located in Pechenga District of Russia's Murmansk Region and is a rock dump composed of the mining waste from the primary Allarechensk sulfide copper-nickel deposit, which was mined by open-cut mining in 19611971 (Figure 3). The main valuable components recovered from the ores of this deposit were nickel, copper, and cobalt.

During the operation of the deposit, man-made landforms developed - an open pit with an area of $1000 \times 300$ meters at the top and a depth of up to $75 \mathrm{~m}$, which is currently flooded, and a waste dump with an elevation above the surrounding areas of approx. 50 meters and an estimated total rock volume of 6.7 million $\mathrm{m}^{3}$ (more than 12 million tons). The hydrology in the area was also significantly modified. After decommissioning, the open pit, the dumps, and the disturbed areas were abandoned. 


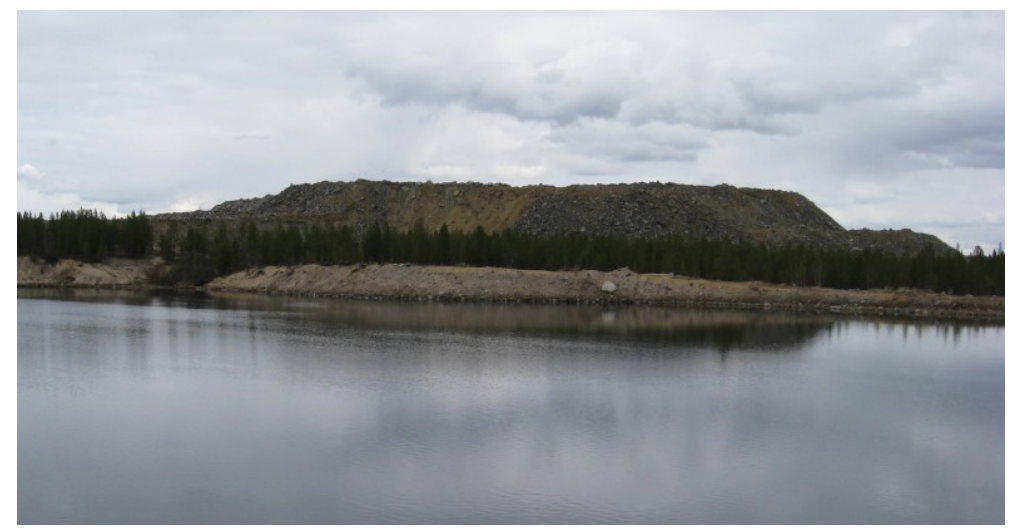

Figure 3. View from the shore of the flooded open-pit mine toward the Allarechensk waste dump

The waste dump contains overburden rocks, mainly barren gneisses, granite gneisses, amphibolites, and host rocks with a varying mineralization degree: peridotites, olivinites, contact amphibolites, etc. The composition of the fine-grained fraction is controlled by the host and overburden rocks that were fragmented during blasting as well as the overburden Quarternary fluvioglacial and glaciolacustrine sediments. The particle size distribution of the dump is very uneven and is characterized by the following averaged parameters: $(-2000$ $+500 \mathrm{~mm})-5-15 \% ;(-500+300 \mathrm{~mm})-15-25 \% ;(-300+150 \mathrm{~mm})-25-35 \% ;(-150+5 \mathrm{~mm})$ $-25-30 \% ;(-5 \mathrm{~mm})-10-15 \%$ [97]. The predominant share of the entire ore mass is concentrated in the fractional interval $-150+40 \mathrm{~mm}$, although disseminated ore fragments can be up to one meter or larger $[6,97,102]$.

The dump's ores belong to two distinctive morphological types: massive (solid) and disseminated (Figure 4) [97, 102]. The main ore minerals in the both types are pyrrhotite, pentlandite, and less often chalcopyrite, which are in a close paragenetic association with magnetite.

The dominant concentrator of nickel in the ore is pentlandite. Its average chemical composition, determined according to microprobe analyzes, in solid ores is as follows (\%): $\mathrm{Ni}$ - 35.3, Fe - 30.8, Co - 0.7, S - 33.2, total - 99.9, formula: $\left(\mathrm{Ni}_{4.65} \mathrm{Fe}_{4.26} \mathrm{Co}_{0.08}\right)_{8.99} \mathrm{~S}_{8.00}$; in disseminated ores (\%): $\mathrm{Ni}-34.1, \mathrm{Fe}-32.0$, $\mathrm{Co}-0.6, \mathrm{~S}$ - 33.0, total - 99.7, formula: $\left(\mathrm{Ni}_{4.50} \mathrm{Fe}_{4.44} \mathrm{Co}_{0.08}\right)_{8.02} \mathrm{~S}_{7.98}$. A relatively small fraction of nickel is represented by pyrrhotite. Its average chemical composition, determined according to microprobe analyzes, in solid ores is as follows (\%): Fe 60.1, Ni 0.3, S 39.5, total 99.9, formula: $\left(\mathrm{Fe}_{6.98} \mathrm{Ni}_{0.03}\right)_{7.01} \mathrm{~S}_{7.99}$; in disseminated ores (\%): Fe 60.6, Ni 0.3, S 38.9, total 99.8, formula: $\left(\mathrm{Fe}_{7.06} \mathrm{Ni}_{0.04}\right)_{7.10} \mathrm{~S}_{7.90}$. Copper is concentrated mainly in tetragonal chalcopyrite. The chemical composition of this 
mineral is almost the same in all ores and corresponds to the following stoichiometry of $(\mathrm{Cu}, \mathrm{Fe}) \mathrm{S}_{2}(\%): \mathrm{Cu}-34.6, \mathrm{Fe}-30.4, \mathrm{~S}-35.0$, total -100.0 . The only cobalt concentrator in the ores is pentlandite.

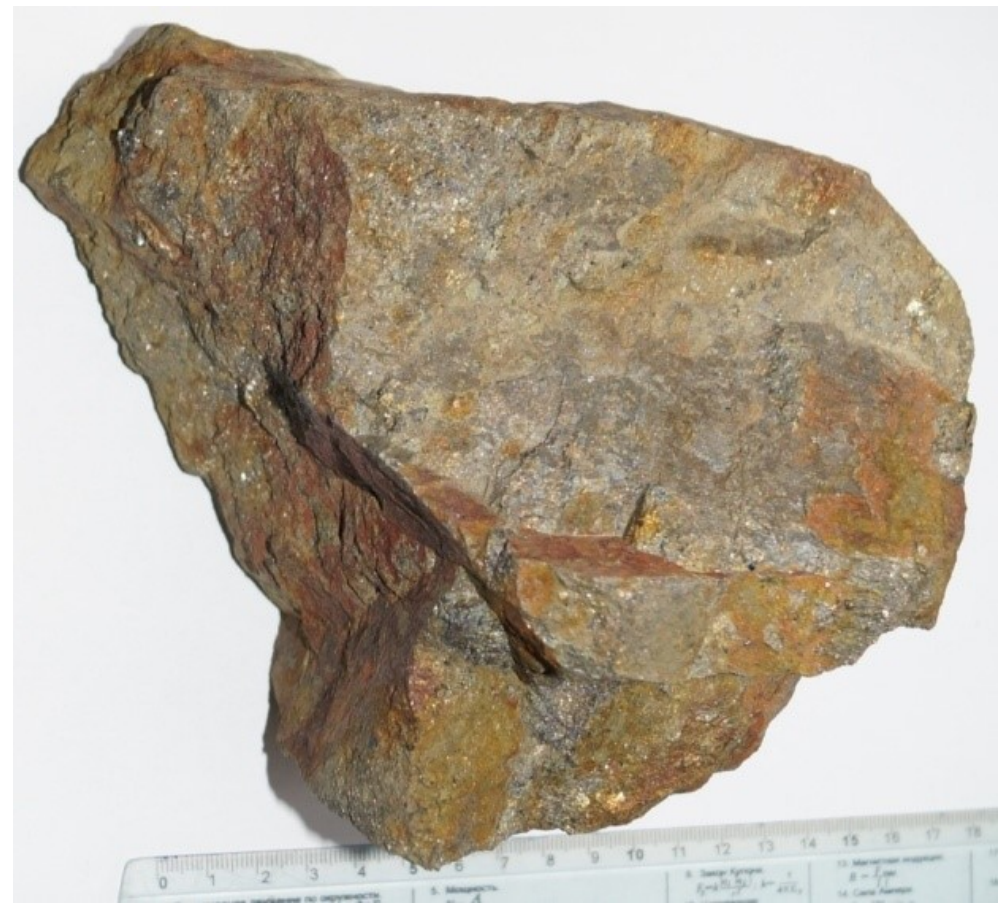

Figure 4. A sample of solid pyrrhotite-pentlandite ore from the Allarechensk anthropogenic deposit.

Atmospheric impacts on primary ores during their long-term storage in a rock dump and the associated changes in the surface properties of sulfides have led to the emergence of oxidized ores. As a result of oxidation, a significant share of the ore has lost its original properties. Where in high-grade primary ores the grades of valuable components are up to $\mathrm{Ni}-18 \%, \mathrm{Cu}-8 \%, \mathrm{Co}-0.3 \%$, in their oxidized counterparts, the highest observed grades never exceed: $\mathrm{Ni}-3.3 \%, \mathrm{Cu}-2.0 \%$, $\mathrm{Co}-0.05 \%$ [6].

Solid pyrrhotite-pentlandite ores are particularly susceptible to oxidation due to the instability of their main minerals, which can be observed visually - the fragments of these ores become coated in an iron hydroxide crust, begin to peel and crumble. In addition to physical degradation, the ores undergo constant chemical 
reactions. As a result of the chemical changes in the ores, characteristic oxidized minerals form, such as covellin $(\mathrm{CuS})$, native copper, violarite, retgersite $(\alpha-$ $\mathrm{NiSO}_{4} \cdot 6 \mathrm{H}_{2} \mathrm{O}$ ) and the like.

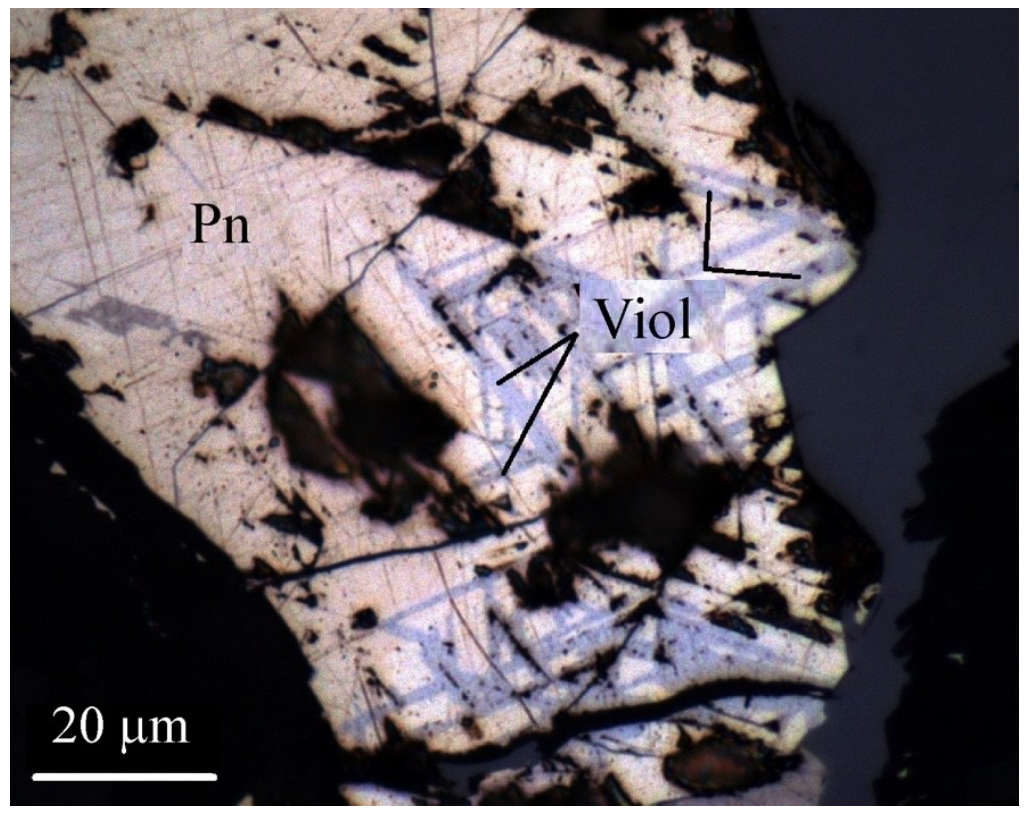

Figure 5. Violarite deportments. Violarite development in pentlandite cleavage, reflected light image: Pn - pentlandite, Viol - violarite.

Many researchers note the prevailing role of the bacterial factor in the oxidation of sulfide minerals $[14,15,1010]$. In the presence of microorganisms, the oxidation rate of $\mathrm{FeSO}_{4}$ increases by tens of thousands of times, which greatly accelerates the degradation of sulfides.

Despite the fact that the site is geographically located in the subarctic zone, thionic acidophilic iron and sulfur-oxidizing bacteria were found in water and ore samples. The isolated bacterial strains showed a high oxidative activity of up to $20-23 \mathrm{~g} / 1 \mathrm{Fe}^{2+}$ per day $[97,102]$.

\subsection{Concentration tailings of copper-nickel ores}

In Murmansk Region, there are three copper-nickel ore tailing storage facilities. The tailing storage facility of Concentrator 1 at the Pechenganickel Operation of Kola MMC, located in the city of Zapolyarny, Murmansk Region, has been in 
operation since 1965 (Figure 6). Tailing Storage Facility 2 in the town of Nickel operated from 1945 to 1994 . The third site accumulated the tailings of an experimental concentrator built in 1957 and is located in the town of Afrikanda. For several years, the concentrator processed the copper-nickel ores of the Pechenga field. Currently, the tailing storage facility is decommissioned [104].

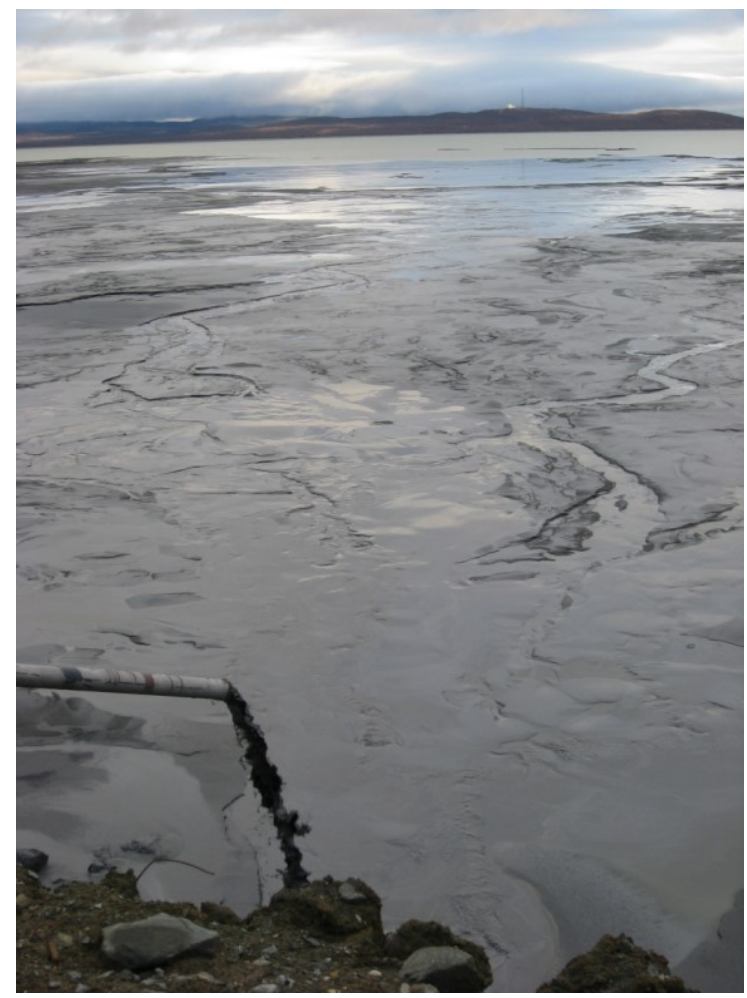

Figure 6. Tailing storage facility of Concentrator 1 at the Pechenganickel operation in Zapolyarny.

Based to their lithology, the concentration tailings of the Pechenganickel operation can be considered silts, and based on their geotechnical properties, belong to silty soils. Such soils dust when dry, and when water-saturated, tend to act as quicksand. Unlike naturally-occurring varieties, anthropogenic ones practically do not contain clay minerals and organic colloids. 
In turn, mature tailings differ from fresh ones by a higher share of ultrafine fractions and a larger specific surface area of the particles. During tailings storage, due to surface drift and suffusion processes, the material is differentiated in terms of density and particle size distribution, which is characteristic of the entire tailing dump volume. At the same time, the physicochemical properties of the surface of most minerals, even those resistant to weathering, become altered [102].

Mineralogical and lithological analysis and particle size analysis showed that all mature tailings samples can be classified into groups (Figure 7). Group 1 is represented by clay-like engineered soils, in which fractions finer than $0.025 \mathrm{~mm}$ prevail. These soils are composed mainly of talc and hydrochlorite. Minor quantities of finely dispersed (colloidal) particles are present in such soils. In a water-saturated state, these soils have a fluid consistency, while in an air-dry state they are found in a stone-like state. This indicates the prominent role of water-colloidal bonds between mineral particles. Based on the share of clay particles proper, such soils can be considered engineered analogues of naturally-occurring loams and sandy loams [102].

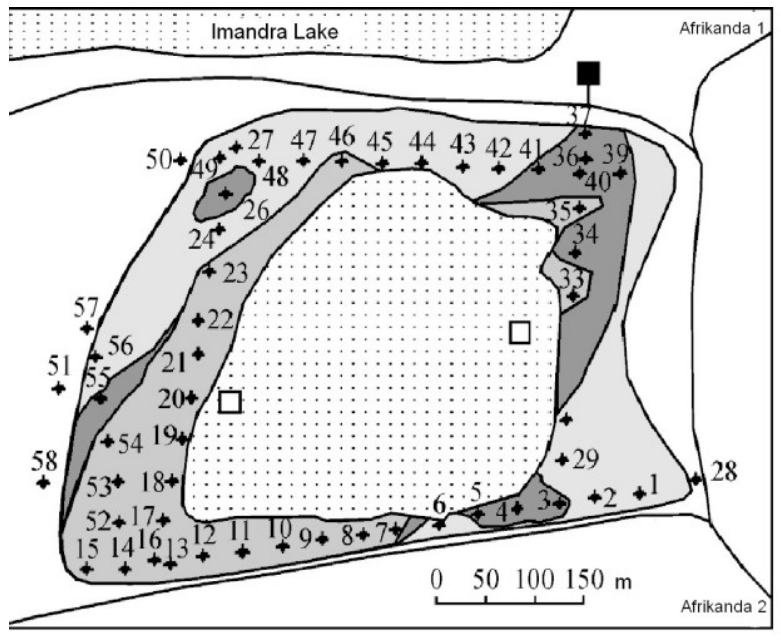

$\square$ Dust sands tails

$\square$ Clay Tails

$\square$ Mixed

Figure 7. Schematic map of the Afrikanda concentrator tailings storage facility. Lithological types of mature tailings [54].

Group 2 is composed of incoherent engineered soils close to naturally-occurring silty sands or silts. The share of particles finer than $0.025 \mathrm{~mm}$ usually does not exceed a few percent, and there are practically no particles finer than $0.01 \mathrm{~mm}$. 
Sometimes, same sample contains both clay-like and incoherent soils. But in this case too, these are spatially separated and represent different layers.

The composition of the various groups of the mature tailings is as shown in Table 1. Comparative analysis of the mineral composition of the fresh and mature tailings revealed a number of differences. The differences caused by hypergenic processes include, first of all, the significant oxidation of sulfide minerals and their substitution with iron hydroxides.

In tailings, same as in dumps, pyrrhotite is oxidized to form free sulfuric acid, affecting both pyrrhotite itself and the pentlandite associated with it. As a result of this effect, violarite $(\mathrm{Ni}, \mathrm{Fe})_{3} \mathrm{~S}_{4}$ forms on the surface of pentlandite, which leads to an increase in porosity and accelerates the weathering of the mineral. Figure 8 shows micrographs of sulfides of mature copper-nickel ore concentration tailings.

Table 1. Composition of copper-nickel ore concentration tailings [104].

\begin{tabular}{|c|c|c|c|}
\hline \multirow{2}{*}{ Minerals } & \multicolumn{3}{|c|}{ Mature tailings } \\
\cline { 2 - 4 } & Clay-like & $\begin{array}{c}\text { Incoherent with clay-like } \\
\text { interlayers }\end{array}$ & Incoherent \\
\hline Olivine & 0 & 0.10 & 0.10 \\
\hline Augite & 1.00 & 1.75 & 4.47 \\
\hline Kersutite & 0.99 & 1.69 & 3.74 \\
\hline Chrysotile & 1.13 & 1.50 & 1.00 \\
\hline Serpophite & 5.16 & 15.25 & 25.50 \\
\hline $\begin{array}{c}\text { Chlorite and } \\
\text { hydrochlorite }\end{array}$ & 55.82 & 34.01 & 6.08 \\
\hline Antigorite & 5.00 & 7.70 & 10.40 \\
\hline Talc & 13.81 & 14.86 & 3.10 \\
\hline Actinolite & 3.00 & 7.60 & - \\
\hline Calcite & - & - & 6.29 \\
\hline Dolomite & - & 2.50 & - \\
\hline Quartz & 1.98 & 1.00 & - \\
\hline Albite & 2.00 & 0.99 & 15.11 \\
\hline Gypsum & 2.11 & 1.00 & 10.05 \\
\hline $\begin{array}{c}\text { Ore (sulfides }+ \\
\text { magnetite) }\end{array}$ & 8.00 & & \\
\hline
\end{tabular}

Hypergenic processes can explain the higher content of chlorite $(\mathrm{Mg}, \mathrm{Fe})_{6}\left[\mathrm{Si}_{4} \mathrm{O}_{10}\right](\mathrm{OH})_{8}$ and hydrochlorites in the mature tailings, which is the highest in clay-like tailings. The consequences of these processes include the almost complete disappearance of calcite $\mathrm{CaCO}_{3}$, which actively interacts with the acidic sulfates formed during the oxidation of sulfides, with the formation of gypsum 
$\mathrm{CaSO}_{4} \cdot 2 \mathrm{H}_{2} \mathrm{O}$. The formation of gypsum is most prominent in clay-like fractions. This mineral also forms in incoherent soils. However, the latter are characterized by high values of the filtration coefficient and, as a result, in the climatic conditions of Murmansk Region, gypsum is completely leached from these.

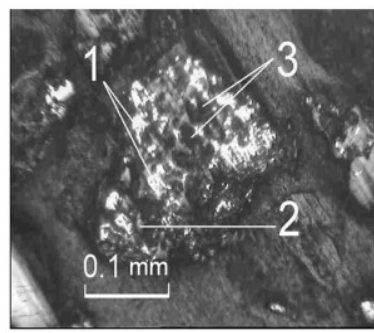

$a$

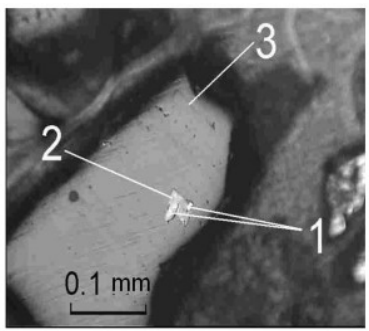

$b$

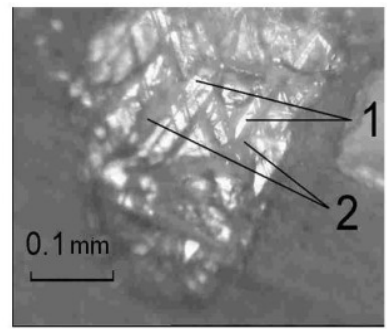

$c$

Figure 8 a) Relics of sulfides, mainly pentlandite, in an aggregate of iron hydroxides. 1 - sulfides; 2 - goethite; 3 - leaching caverns; b) pentlandite (1) and pyrrhotite iron hydroxides (2) - inclusion in chromium-containing magnetite (3); c) selective substitution of monoclinic pyrrhotite with iron hydroxides, 1 - hexagonal pyrrhotite; 2 - goethite [104].

\subsection{Pechenganickel granulated slag dumps}

Pechenganickel smelter slag dumps dating back to 1945 can be considered an anthropogenic deposit containing more than 45 million tons of material [105]. Fresh and mature slags after 15 years of storage were studied [106, 107].

The difference between mature and fresh slags lies in the noticeable increase in the share of the $-0.1 \mathrm{~mm}$ fraction. Significant heterogeneity of the mature slags in terms of particle size distribution, characteristic of all size fractions, is noted. Obviously, this is due to the differentiation of the material, both at the stage of stockpiling and during storage, as well as possible hypergenic processes (Figure 9). Table 2 shows the geotechnical properties of the mature slags.
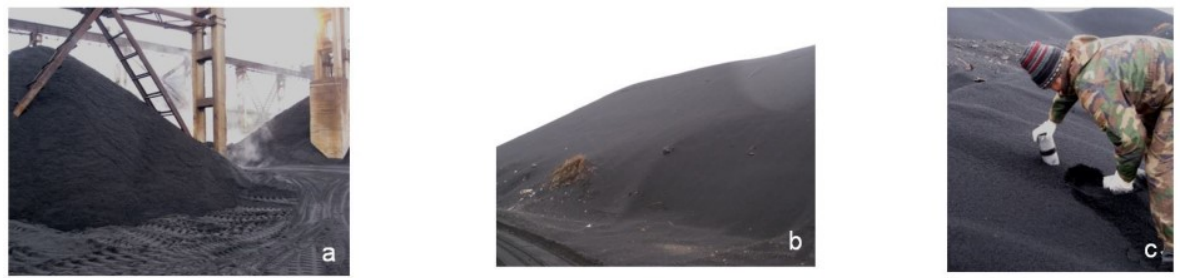

Figure 9. Pechenganickel fresh granular slags (a), mature slag dump (b), sampling of undisturbed slags (c) 
Table 2. Properties of mature slags.

\begin{tabular}{|c|c|c|c|c|c|}
\hline \multirow{2}{*}{ Indicator } & \multicolumn{2}{|c|}{ Density, g/cm3 } & \multirow{2}{*}{ Moisture, \% } & Porosity, \% & $\begin{array}{c}\text { Fraction } \\
-0.1 \mathrm{~mm}, \%\end{array}$ \\
\cline { 2 - 6 } & true & natural state & 3.36 & 49.77 & 0.63 \\
\hline Mean & 3.32 & 1.73 & 0.79 & 4.53 & 0.40 \\
\hline $\begin{array}{c}\text { Standard } \\
\text { deviation }\end{array}$ & 0.04 & 0.14 & 0.63 & 20.56 & 0.16 \\
\hline Variance & 0.002 & 0.02 & \multicolumn{2}{l}{} \\
\hline
\end{tabular}

The chemical composition of the fresh slags (1) and mature slags (2) is shown in Table 3. The high content of magnesium oxide and the low content of iron oxides is most likely associated with a change in the composition of the concentrates entering the pyrometallurgical process stage, as well as with the features of the smelting process.

In general, higher non-ferrous metal content in the fresh slags can be observed, which is due to both the smelting of higher-grade concentrates and the oxidation processes in the dump. In the fresh slags, the nickel grade is significantly higher in the size classes -0.1 and $+5 \mathrm{~mm}$ (Figure 10). However, given their low yield ( $0.09 \%$ and $0.63 \%$, respectively), this observation is hardly of process relevance. Nickel grade of the mature slags is also higher in fine size classes, and the yield of $-0.25 \mathrm{~mm}$ fractions averages approx. 3\%. Copper and cobalt are more evenly distributed in the fresh slags. Mature slags are characterized by an increased copper content in the size class $-0.5 \mathrm{~mm}$ and cobalt in the size class $-0.1 \mathrm{~mm}$. When mature slags are recycled, for example, in the production of building materials, the fraction $-0.25 \mathrm{~mm}$ can be isolated for the further recovery of non-ferrous metals.

Table 3. The chemical composition of the Pechenganickel fresh slags (1) and mature slags (2).

\begin{tabular}{|c|c|c|c|c|c|c|c|c|c|c|}
\hline \multirow{2}{*}{ Slag } & \multicolumn{10}{|c|}{ Grade, $\%$} \\
\cline { 2 - 12 } & $\mathrm{TiO}_{2}$ & $\mathrm{~K}_{2} \mathrm{O}$ & $\mathrm{Fe}_{2} \mathrm{O}_{3}$ & $\mathrm{FeO}$ & $\mathrm{CaO}$ & $\mathrm{MgO}$ & $\mathrm{Na}_{2} \mathrm{O}$ & $\mathrm{A}_{2} \mathrm{O}_{3}$ & $\mathrm{MnO}$ & $\mathrm{SiO}_{2}$ \\
\hline 1 & 0.71 & 0.53 & 12.00 & 23.51 & 2.09 & 13.31 & 1.04 & 6.03 & 0.11 & 40.61 \\
\hline 2 & 0.80 & 0.72 & 10.03 & 26.55 & 3.16 & 10.39 & 1.12 & 6.81 & 0.13 & 40.53 \\
\hline
\end{tabular}

A mineralogical assessment of the Pechenganikel dumped granular slags in order to examine the feasibility of recycling was undertaken in the early 1980s by Volokhonsky and Rezhenova [108]. According to their findings, the granular slags are mostly composed of magnesian-iron glass containing 1-2\% olivine, as well as sulfide inclusions and finely impregnated magnetite. Glass in the slags practically does not contain an admixture of nonferrous metals in an isomorphic state, these are completely concentrated in the sulfide alloy inclusions. According to [108], the alloy is a pyrrhotite solid solution containing $\mathrm{Fe}$ (49$55 \%), \mathrm{S}(34-39 \%)$, Ni (4-8\%), Cu (2-6\%), Co (0.2-0.3\%). Sulfide inclusions in the slag have a much lower nickel grade compared to matte, which is due to a higher crystallization temperature of the slag relative to matte [108]. 


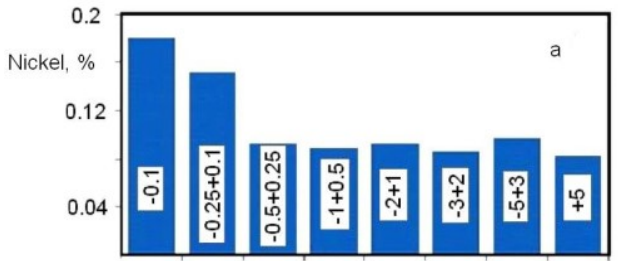

Particle size, $\mathrm{mm}$

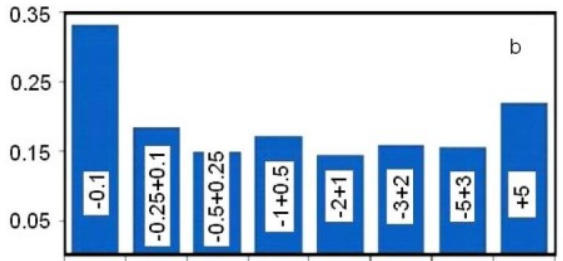

Particle size, $\mathrm{mm}$

Figure 10. The distribution of nickel across the size classes of the mature slags (a) and fresh slags (b). Nickel, \% - Particle size, mm

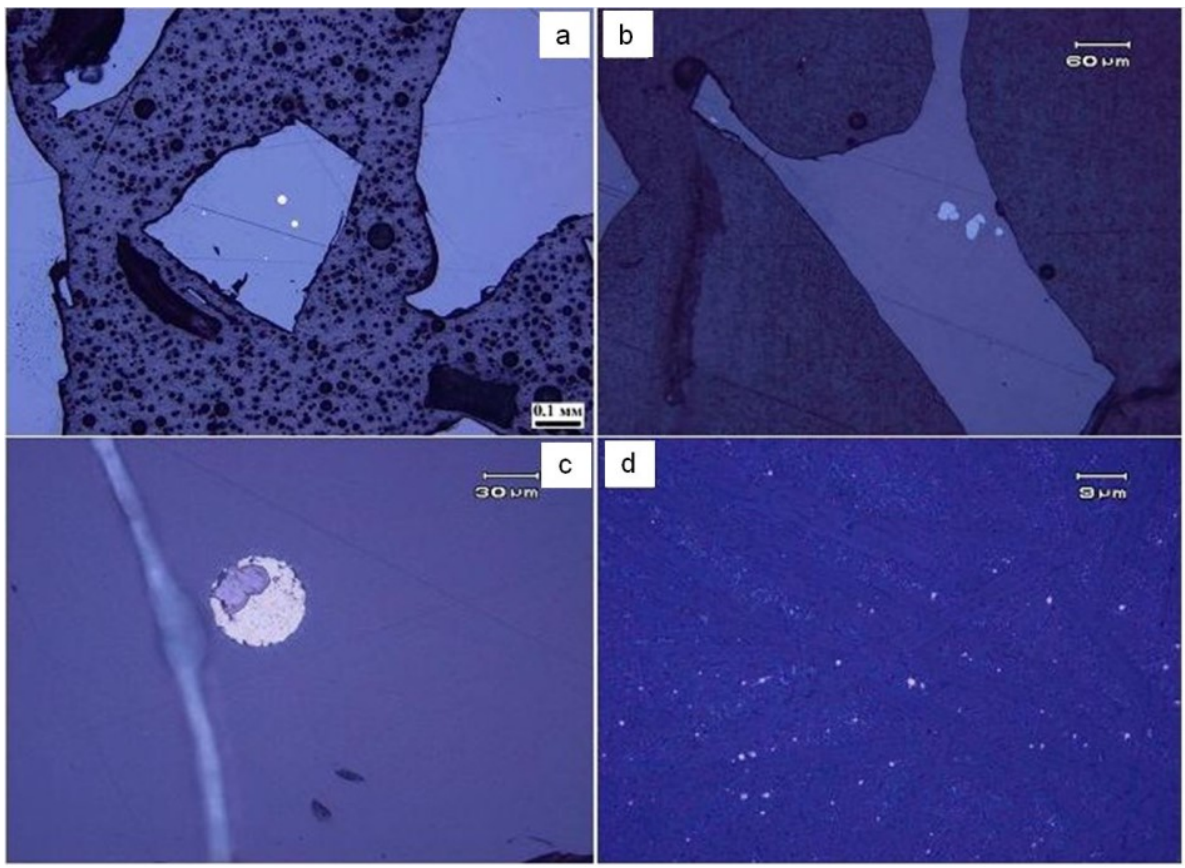

Figure 11. Fresh Pechenganickel slags: a - rounded sulfides; $b$ - oval-shaped sulfide precipitation and intergrowth; $\mathrm{c}$ - a coarse sulfide grain; $\mathrm{d}$ - fine inclusions of rounded sulfides between needle-shaped olivine crystals.

According to more recent studies, three types of slag particles were identified by optical methods: homogeneous, fine grained, and coarse grained [109]. The slag is a heterogeneous silicate melt with inclusions of matte, olivine, and pyrrhotite beads. The 
silicate melt has a cluster structure, consists of glass of complex composition with nanoscale sections (clusters) enriched in Fe-Si-Mg-S. The composition of the silicate melt is generally stable, except for the areas of olivine crystallization. In these areas, due to the transition of $\mathrm{MgO}$ and $\mathrm{SiO}_{2}$ into olivine, the glass has a reduced content of $\mathrm{MgO}$ and $\mathrm{SiO}_{2}$ and an increased of $\mathrm{FeO}$, pyrrhotite forms due to the excess of $\mathrm{S}$. The presence of $\mathrm{Ni}$ and Co impurities was found only in slag containing matte beads. It is concluded that the recovery of valuable components is advisable only from coarse slag particles.

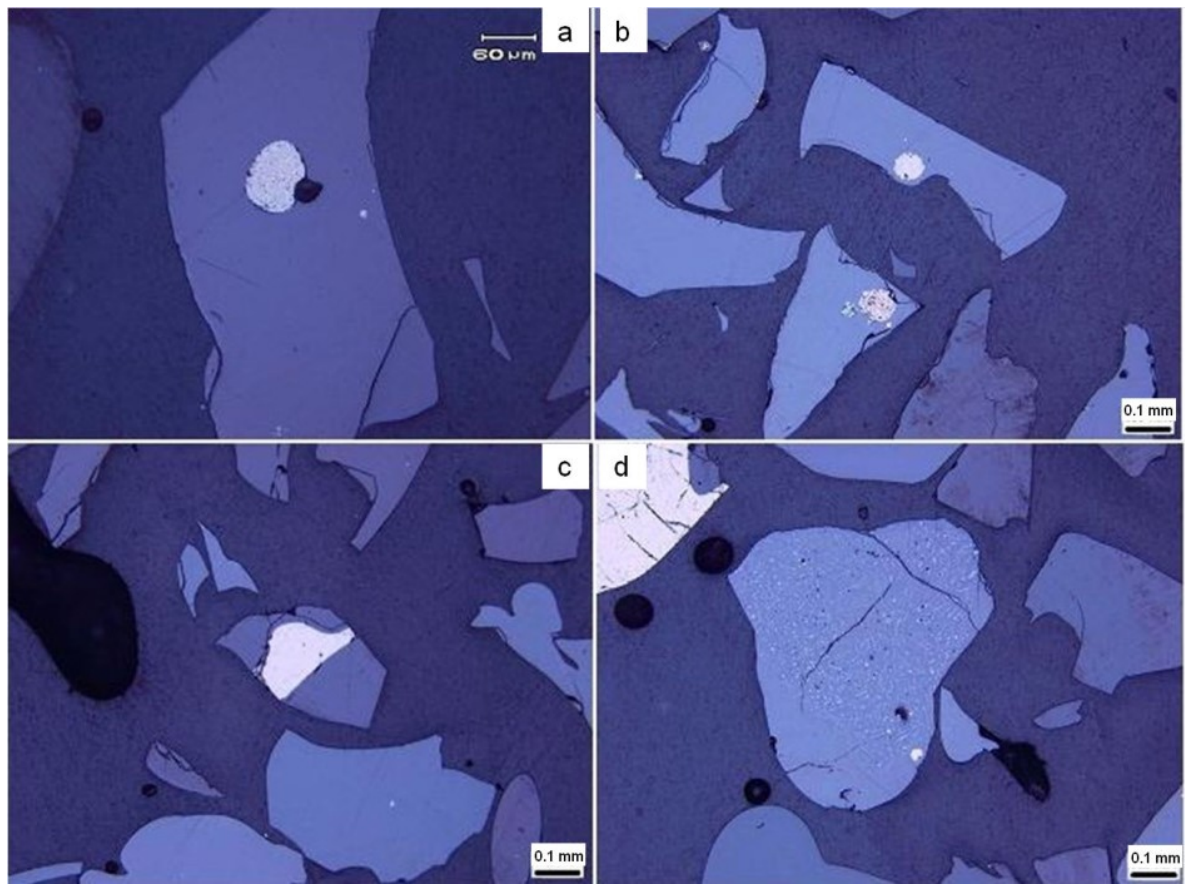

Figure 12. Mature Pechenganickel slags: a, b - coarse, rounded sulfide precipitates; c, $d$ - curved sulfides; $d$ - inclusions of sulfides between olivine needles.

Sulfide inclusions in the fresh granular slag are distributed unevenly and not in all grains of the bulk mass (slag matrix), consisting of olivine and glass (Figure 11 a). Sulfides in the fresh slag are most often round in shape (balls, drops), oval precipitates are less common, intergrowths of individual sulfide grains have also been found (Figure $11 \mathrm{~b}$ ). Sulfide sizes range from 5 to 20 microns. Larger grains up to $50 \mu \mathrm{m}$ are also rarely observed (Figure $11 \mathrm{c}$ ). Matrix grains (apparently glass) are often observed, in which 
skeletal needle-shaped olivine crystals are present, forming a spinifex structure (Figure 11 d). Between these needle-shaped olivine crystals in the glass matrix, framing the needleshaped olivine, multiple fine sulfide inclusions sized 1.5-2.0 $\mu \mathrm{m}$ are found (Figure $11 \mathrm{~d}$ ).

Sulfide inclusions in the mature slags in terms of form are both rounded precipitates (Figure $12 \mathrm{a}, \mathrm{b}$ ), similar to fresh slag sulfides, and complex sulfide formations with a curved shape (Figure $12 \mathrm{c}, \mathrm{d}$ ). The sulfide grains here are significantly coarser than in the fresh slags, and a few sulfide grains are visible to the naked eye, being $0.3-0.4 \mathrm{~mm}$ in size. The sulfides vary in size from very fine (5-10 microns) to coarser (20-70 microns).

Table 4. The chemical composition of the sulfides (wt $\%$ ) in the Pechenganickel slags.

\begin{tabular}{|c|c|l|l|l|l|}
\hline Component & SHL-2_1 & SHL-2_2 & SHL-2_3 & SHT-3_2 & SHT-3_3 \\
\hline $\mathrm{Fe}$ & 55.15 & 52.98 & 49.12 & 33.97 & 36.97 \\
\hline $\mathrm{Cu}$ & 6.15 & 7.56 & 10.64 & 8.24 & 7.23 \\
\hline $\mathrm{Ni}$ & 3.86 & 4.45 & 4.82 & 22.90 & 19.43 \\
\hline $\mathrm{Co}$ & 0.26 & 0.27 & 0.27 & 0.97 & 0.80 \\
\hline $\mathrm{Cr}$ & 0.19 & 0.16 & 0.09 & - & 0.06 \\
\hline $\mathrm{S}$ & 32.91 & 32.85 & 32.08 & 32.30 & 31.70 \\
\hline Total & 98.51 & 99.83 & 98.66 & 98.38 & 98.25 \\
\hline \multicolumn{7}{|c|}{ Crystal chemical formulas } \\
\hline SHL-2_1 & $\left(\mathrm{Fe}_{7.70} \mathrm{Cu}_{0.76} \mathrm{Ni}_{0.51} \mathrm{Co}_{0.03} \mathrm{Cr}_{0.03}\right)_{9.03} \mathrm{~S}_{8}$ \\
\hline SHL-2_2 & $\left(\mathrm{Fe}_{7.41} \mathrm{Cu}_{0.93} \mathrm{Ni}_{0.59} \mathrm{Co}_{0.04} \mathrm{Cr}_{0.02}\right)_{8.99} \mathrm{~S}_{8}$ \\
\hline SHL-2_3 & $\left(\mathrm{Fe}_{7.03} \mathrm{Cu}_{1.34} \mathrm{Ni}_{0.66} \mathrm{Co}_{0.04} \mathrm{Cr}_{0.02}\right)_{9.09} \mathrm{~S}_{8}$ \\
\hline SHT-3_2 & $\left(\mathrm{Fe}_{4.83} \mathrm{Ni}_{3.09} \mathrm{Cu}_{1.03} \mathrm{Co}_{0.13}\right)_{9.08} \mathrm{~S}_{8}$ \\
\hline SHT-3_2 & $\left(\mathrm{Fe}_{5.36} \mathrm{Ni}_{2.68} \mathrm{Cu}_{0.92} \mathrm{Co}_{0.11} \mathrm{Cr}_{0.01}\right)_{9.08} \mathrm{~S}_{8}$ \\
\hline
\end{tabular}

Note:The analyzes were carried out at the IMin Laboratory of Mineral Physics and Experimental Mineralogy, Ural Branch of the Russian Academy of Sciences, using an INCA-200 EDS spectrometer. Lab technician E.I. Churin.

It should be noted that slag dumps in Nickel are exposed to strong weathering agents: atmospheric precipitation (acid rain) and mine water entering the slag dump.

\section{A study of processing methods for copper-nickel mineral feeds.}

\subsection{Further recovery of non-ferrous metals by flotation.}

\subsubsection{Flotation of the Pechenganickel copper-nickel ore concentration tailings.}

According to rough estimates, the concentration waste of Kola MMC contains more than 120 thousand tons of non-ferrous metals $(\mathrm{Ni}, \mathrm{Cu}, \mathrm{Co})$ [110]. The mineral composition of the sample was studied using artificial thin sections in reflected light 
using an Ultraphot-3 (Opton) microscope by Labor mikroskopes and a POLAM P311 (LOMO) microscope with a magnification of up to $1500 \mathrm{x}$, resolution up to 0.2 $\mu \mathrm{m}$. Grain sizes were measured using an MOV-1-15x attachment to optical microscopes; the minimum measurable grain size is $0.0025 \mathrm{~mm}$.

The analysis showed that the main rock minerals in the tailings are serpentine, pyroxene, amphiboles, olivine, and talc. The main ore minerals are represented by sulfides - pyrrhotite, pentlandite, chalcopyrite, and oxides - magnetite, chrome spinelide, ilmenite. The content of the main components in the sample was as follows: $\mathrm{Ni}-0.22 \%, \mathrm{Cu}-0.08 \%$, Co $-0.01 \%, \mathrm{Fe}_{\text {total }}-13.64 \%, \mathrm{~S}-0.90 \%$.

Particle size distribution of the tailings sample and the distribution of components by size classes are shown in Table 5 . The test sample is by $50 \%$ composed of material sized $0.071 \mathrm{~mm}$. In all size classes, similar contents of $\mathrm{Ni}$ and $\mathrm{Cu}$ are observed, no concentration of non-ferrous metals in any size class is observed. With a decrease in the size class, an increase is observed in the content of $\mathrm{Fe}_{\text {total }}$ and $\mathrm{S}$, which is due to an increase in the amount of pyrrhotite and magnetite in the finer classes.

Table 5. Particle size distribution of the tailings sample and the distribution of components by size classes.

\begin{tabular}{|c|c|c|c|c|c|c|c|c|c|c|c|}
\hline \multirow{2}{*}{$\begin{array}{c}\text { Size class, } \\
\mathrm{mm}\end{array}$} & \multirow{2}{*}{$\begin{array}{c}\text { Yield, } \\
\%\end{array}$} & \multicolumn{5}{|c|}{ Grade, $\%$} & \multicolumn{5}{|c|}{ Distribution, $\%$} \\
\hline & & $\mathrm{Ni}$ & $\mathrm{Cu}$ & Co & $\mathrm{Fe}_{\text {total }}$ & $\mathrm{S}$ & $\mathrm{Ni}$ & $\mathrm{Cu}$ & $\mathrm{Co}$ & $\mathrm{Fe}_{\text {total }}$ & $\mathrm{S}$ \\
\hline+0.16 & 9.03 & 0.24 & 0.100 & 0.010 & 9.87 & 0.56 & 9.76 & 10.93 & 9.53 & 6.53 & 5.67 \\
\hline$-0.16+0.10$ & 20.43 & 0.23 & 0.094 & 0.010 & 10.37 & 0.57 & 21.50 & 23.17 & 21.57 & 15.53 & 13.03 \\
\hline$-0.10+0.071$ & 20.87 & 0.23 & 0.088 & 0.010 & 11.35 & 0.67 & 21.70 & 22.07 & 21.87 & 17.37 & 15.53 \\
\hline$-0.071+0.05$ & 11.03 & 0.22 & 0.081 & 0.010 & 12.40 & 0.76 & 10.97 & 10.83 & 11.00 & 10.03 & 9.33 \\
\hline$-0.05+0.020$ & 23.30 & 0.21 & 0.070 & 0.010 & 15.34 & 1.06 & 21.90 & 19.70 & 22.10 & 26.20 & 27.47 \\
\hline-0.020 & 15.33 & 0.20 & 0.072 & 0.009 & 21.65 & 1.70 & 14.17 & 13.30 & 13.93 & 24.33 & 28.97 \\
\hline Total & 100.0 & 0.22 & 0.083 & 0.010 & 13.64 & 0.90 & 100.0 & 100.0 & 100.0 & 100.0 & 100.0 \\
\hline
\end{tabular}

Mineralogical analysis of the unlocking of minerals showed that about $5 \%$ of the total sulfide mass was unlocked in the size fraction larger than $0.071 \mathrm{~mm}$. The share of free sulfide grains increases with a decrease in the size class and reaches $50 \%$ in the size class $0.05+0.02 \mathrm{~mm}$ and $80 \%$ in the size class $-0.02 \mathrm{~mm}$. The amount of free magnetite also increases. All sulfides and oxides are present is an unlocked form. Pyrrhotine prevails among sulfides, magnetite prevails among oxides (Figure 13).

Mineralogical studies established that in all size fractions of the tailings, there are signs of sulfide oxidation. It is represented by rims around sulfides, veinlets in silicates and matrix between goethite-like iron hydroxide grains. The development of violarite in pentlandite can also be related to oxidation processes. Despite the fact that the scope of substitution is minor, the development of oxidation in the form of film formations is possible on all sulfide grains, which can negatively affect the flotation performance (Figure 14). 


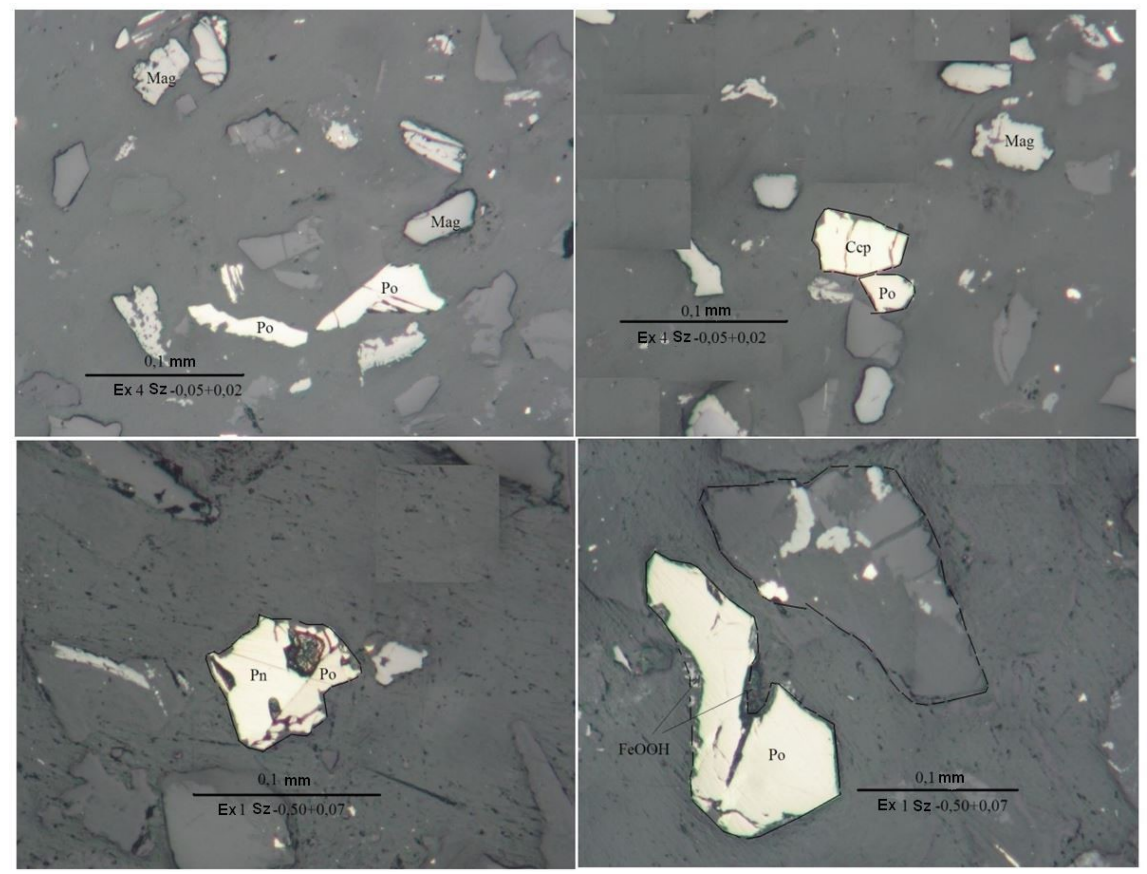

Figure 13. Morphology of the unlocked particles of sulfides and magnetite; Pn - pentlandite, Ccp - chalcopyrite, Po - pyrrhotite, Mag - magnetite.

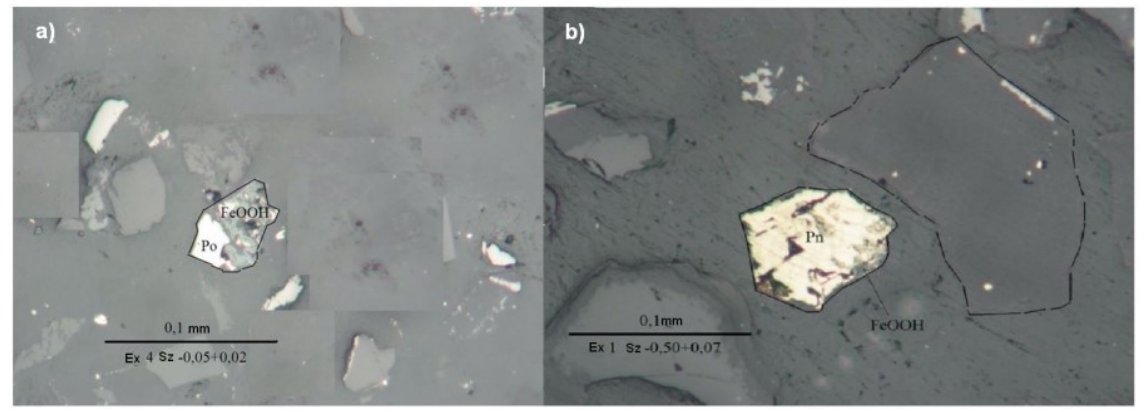

Figure 14. An example of the development of iron hydroxides in pyrrhotite (a) and pentlandite (b); Pn - pentlandite, $\mathrm{Po}$ - pyrrhotite, FeOOH - iron hydroxides. 
Sulfide intergrowths are represented by four main types (Figure 15) [111]. Type 1 intergrowths are cross-linked sulfide intergrowths with scaly silicate minerals identified as antigorite and chlorite. The interstitial mass of sulfides in these intergrowths consists, as a rule, of a mixture of pyrrhotite, pentlandite and chalcopyrite, but is sometimes composed of one of the sulfides. The intergrowths are predominantly sulfide-silicate; a small amount of magnetite may be present. Type 2 intergrowths are sulfide intergrowths with fine-grained serpentine varieties (lysardite and chrysotile), as well as amphiboles and talc. The internal structure is characterized by diverse impregnation and veinlets of sulfides in serpentine, magnetite is often present.

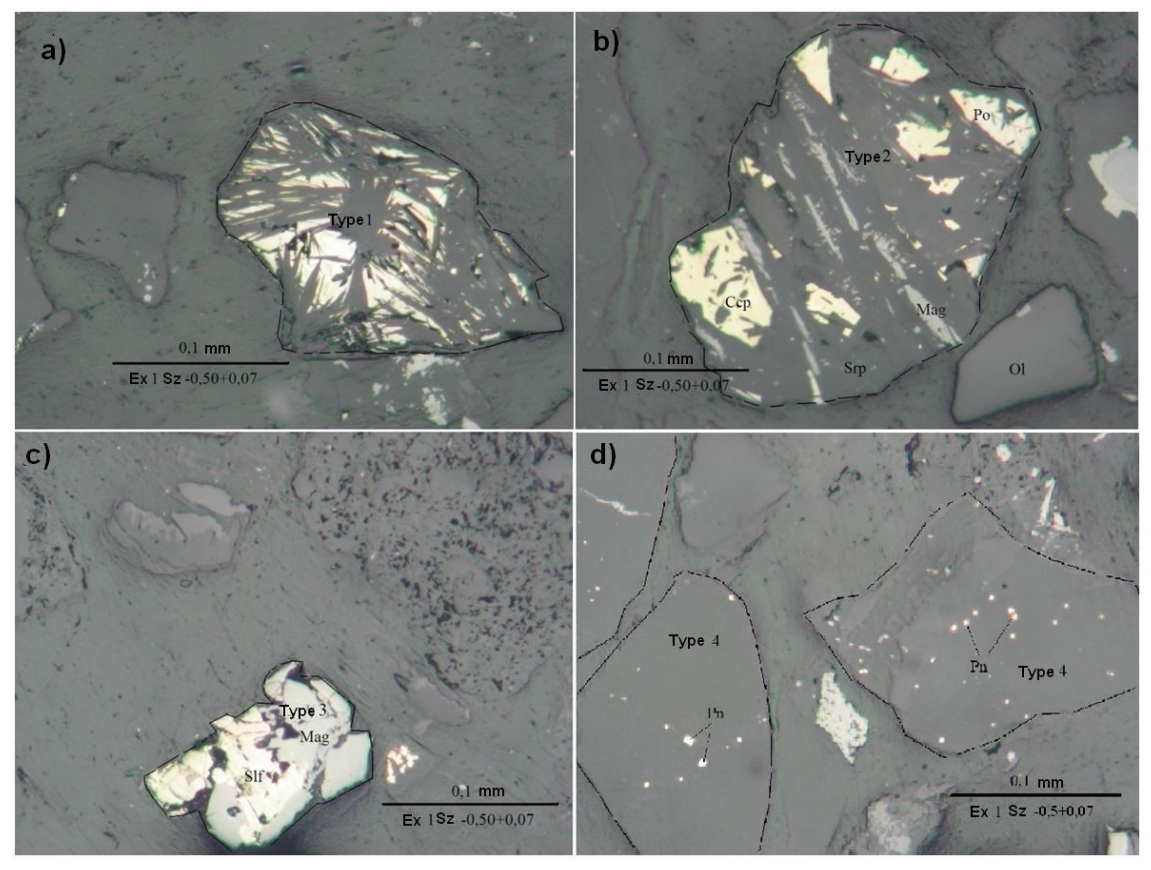

Figure 15. Typical intergrowths of sulfide minerals: Type 1 (a), Type 2 (b), Type 3 (c), Type 4 (d); Slf - sulfides, Mag - magnetite, Pn - pentlandite, Po - pyrrhotite, Ccp - chalcopyrite, Srp - serpentine, Ol - olivine.

The sulfide part of the intergrowths varies greatly in composition; it can consist of pyrrhotite, pentlandite, chalcopyrite, or their intergrowths. Type 3 intergrowths are represented by intergrowths of sulfides with magnetite. All sulfides are present in the composition of the intergrowths, but mainly pyrrhotite and pentlandite. The share of 
sulfides in the intergrowths and the size of the inclusions vary greatly. This determines the presence of intergrowths in the finest fractions of the tailings. Type 4 intergrowths are inclusions of pentlandite in serpentine. The inclusions of pentlandite are very fine, usually 1-2 microns. Chalcopyrite, pyrrhotite, and magnetite may be present in inclusions, but these mainly consist of pentlandite. The tailings also contain intergrowths of magnetite with silicates, in which rare grains of sulfides of various compositions may be found.

The presence of intergrowths of types 1-3 in the coarse tailings fractions (larger than $0.05 \mathrm{~mm}$ ) suggested the possibility of unlocking the sulfides when the material was reground to this size; type 4 intergrowths are non-unlockable intergrowths and inevitably lost.

Grinding of the studied concentration waste samples for flotation experiments was carried out in a ball mill at a S:L ratio of 1:0.6. Flotation performance was evaluated in mechanical flotation cells. The flotation process included rougher and scavenger flotations. The experiments were carried out in an open circuit using tap water. The required $\mathrm{pH}$ value was achieved by adding soda ash $\left(\mathrm{Na}_{2} \mathrm{CO}_{3}\right)$. Potassium butyl xanthate $(\mathrm{Kx})$ and sodium butyl aeroflot (Af) were used as collectors; copper sulfate was used to activate sulfide minerals. Soda ash and xanthate were ground.

The flotation performance of the stored waste was studied while changing the grinding size from $54 \%$ to $90 \%$ passing $-0.045 \mathrm{~mm}$. The results of flotation tests confirmed the possibility of unlocking the intergrowths by grinding. The highest recovery of non-ferrous metals into the rougher flotation froth at their lowest content in the flotation tailings was obtained at a grinding size of $90 \%$ passing $-0.045 \mathrm{~mm}$ (Figure 16).

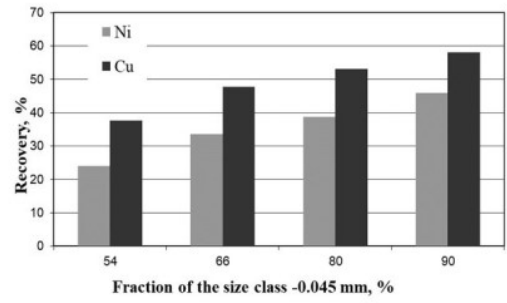

a)

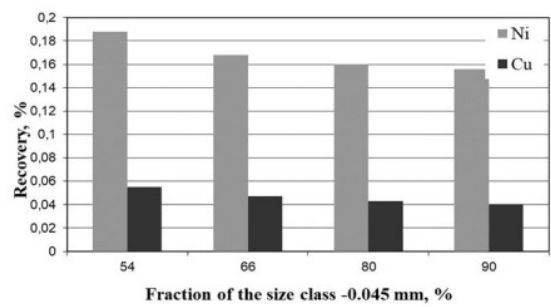

b)

Figure 16. Recovery of non-ferrous metals into the rougher flotation froth (a) and the content of non-ferrous metals in the flotation tailings (b) for various grinding sizes. Recovery, $\%$ - Grade, $\%$ - Fraction of the size class $-0.045 \mathrm{~mm}, \%$

At a grinding size of $90 \%$ passing $-0.045 \mathrm{~mm}$, flotation tests were carried out at various $\mathrm{pH}$ values: in an alkaline $(\mathrm{pH}=9.8)$ and slightly acidic $(\mathrm{pH}=6.3)$ environment. The results are presented in Table 6 . Tests were carried out at the same collector flow rate. 
Table 6. Flotation performance in an alkaline and acidic environment.

\begin{tabular}{|c|c|c|c|c|c|c|}
\hline \multirow{2}{*}{ Product } & \multirow{2}{*}{ Yield, \% } & \multicolumn{2}{|c|}{ Grade, $\%$} & \multicolumn{2}{|c|}{ Recovery, \% } & \multirow{2}{*}{$\begin{array}{c}\text { Reagent flow rate, } \\
\mathrm{g} / \mathrm{t}\end{array}$} \\
\hline & & $\mathrm{Ni}$ & $\mathrm{Cu}$ & $\mathrm{Ni}$ & $\mathrm{Cu}$ & \\
\hline \multicolumn{7}{|c|}{$p H=6.3 ; \mathrm{H}_{2} \mathrm{SO}_{4}-1,5 \mathrm{~kg} / \mathrm{t}$} \\
\hline Froth & 22.03 & 0.418 & 0.216 & 41.69 & 56.62 & \multirow{3}{*}{$\begin{array}{c}\text { Xanthate - } 135 \\
\text { Aeroflot - } 95 \\
\text { CuSO }_{4-} 30\end{array}$} \\
\hline Tailings & 77.97 & 0.165 & 0.047 & 58.31 & 43.38 & \\
\hline Feed & 100.0 & 0.221 & 0.084 & 100.0 & 100.0 & \\
\hline \multicolumn{7}{|c|}{$p \mathrm{H}=9.8 ; \mathrm{Na}_{2} \mathrm{CO}_{3}-3 \mathrm{~kg} / \mathrm{t}$} \\
\hline Froth & 24.46 & 0.392 & 0.199 & 44.21 & 59.36 & \multirow{3}{*}{$\begin{array}{c}\text { Xanthate - } 135 \\
\text { Aeroflot - } 95 \\
\text { CuSO }_{4}-30\end{array}$} \\
\hline Tailings & 75.54 & 0.160 & 0.044 & 55.79 & 40.64 & \\
\hline Feed & 100.0 & 0.217 & 0.082 & 100.0 & 100.0 & \\
\hline
\end{tabular}

The test results that the best process performance indicators, both in terms of froth properties and the non-ferrous metals grade of the flotation tailings, were achieved in an alkaline environment. The recovery of nickel and copper into the froth was in this case $2.5 \%$ and $2.7 \%$ higher than in an acidic environment with a similar product grade. A concentrate of this grade can subsequently be fed to hydrometallurgical process [112]. The concentration of valuable components was 1.8 for nickel and 2.4 for copper. The introduction of two successive cleaner flotations without the addition of reagents made it possible to increase the nickel and copper grade to $0.65 \%$ and $0.46 \%$ after the cleaner and to $0.96 \%$ and $0.94 \%$ after the recleaner flotation.

In connection with the presence of signs of sulfide oxidation in the sample material, the effect of adding a sulfidizer on the flotation performance was examined. Sodium sulfide $\left(\mathrm{Na}_{2} \mathrm{~S}\right)$ was used as a sulfidizer. Various options for adding the reagent were considered to the grinding and flotation circuit with preliminary agitation. The reagent flow rate was, g/t: xanthate - 145 (grinding), aeroflot $-95, \mathrm{CuSO}_{4}-30, \mathrm{Na}_{2} \mathrm{~S}-40$. Flotation was carried out at $\mathrm{pH}=9.8$.

The results showed the effectiveness of sodium sulfide. The use of the reagent made it possible to increase the recovery of nickel and copper and to obtain flotation tailings relatively low in non-ferrous metals. The best performance was achieved by feeding the reagent to the flotation circuit (Table 7), which allowed to increase the recovery of $\mathrm{Ni}$ and $\mathrm{Cu}$ by $1.3 \%$ and $1 \%$, respectively.

The conventional reagents used in the flotation of sulfide minerals are sulfhydryl collectors, whose aqueous solutions are unstable and decompose with the release of toxic products. In connection with the foregoing, the possibility of using a complexing reagent based on hydroxamic acids (HA) as a collector was examined. The HA reagent is formulated similarly to the reagent IM-50 and is a 75/25 mixture of alkyl $\left(\mathrm{C}_{7}-\mathrm{C}_{8}\right)$ hydroxamic and corresponding carboxylic acids. Hydroxamic acids, being bidentate ligands, are capable of forming stable complexes with non-ferrous metal ions and iron. The possibility of their use for the recovery of non-ferrous metals was shown earlier in the flotation of copper-nickel ore [113]. 
Table 7. Flotation performance using sulfhydryl collectors and sodium sulfide.

\begin{tabular}{|c|c|c|c|c|c|c|}
\hline \multirow{2}{*}{ Product } & \multirow{2}{*}{ Yield, $\%$} & \multicolumn{2}{|c|}{ Grade, $\%$} & \multicolumn{2}{c|}{ Recovery, $\%$} & \multirow{2}{*}{ Note } \\
\cline { 3 - 6 } & & $\mathrm{Ni}$ & $\mathrm{Cu}$ & $\mathrm{Ni}$ & $\mathrm{Cu}$ & \\
\hline Froth & 27.50 & 0.383 & 0.185 & 46.84 & 62.15 & \multirow{2}{*}{-} \\
\hline Tailings & 72.50 & 0.165 & 0.043 & 53.16 & 37.85 & \multirow{2}{*}{ Na2S to grinding - } \\
\hline Feed & 100.00 & 0.225 & 0.082 & 100.00 & 100.00 & \\
\hline Froth & 28.38 & 0.378 & 0.185 & 47.70 & 62.54 & \multirow{2}{*}{ Na2S to flotation } \\
\hline Tailings & 71.62 & 0.164 & 0.044 & 52.30 & 37.46 & \multirow{2}{*}{} \\
\hline Feed & 100.00 & 0.225 & 0.084 & 100.00 & 100.00 & \\
\hline Froth & 28.56 & 0.374 & 0.179 & 48.13 & 63.09 & \multirow{2}{*}{} \\
\hline Tailings & 71.44 & 0.161 & 0.042 & 51.87 & 36.91 & \multirow{2}{*}{} \\
\hline Feed & 100.00 & 0.222 & 0.081 & 100.00 & 100.00 & \\
\hline
\end{tabular}

The HA reagent was tested in the flotation of samples of the stored copper-nickel ore concentration waste in combination with xanthate at a ratio of $1: 1$ [113]. The results are close to the results of tests using xanthate and aeroflot, and the recovery of nickel into the froth in this case was $48.91 \%$, which is $2.07 \%$ higher than when using a composition of sulfhydryl collectors (Table 8).

Table 8. Flotation performance using the HA complexing reagent.

\begin{tabular}{|c|c|c|c|c|c|c|}
\hline \multirow{2}{*}{ Product } & \multirow{2}{*}{ Yield, \% } & \multicolumn{2}{|c|}{ Grade, \% } & \multicolumn{2}{c|}{ Recovery, \% } & \multirow{2}{*}{$\begin{array}{c}\text { Reagent flow } \\
\text { rate, } \mathrm{g} / \mathrm{t}\end{array}$} \\
\cline { 3 - 6 } & & $\mathrm{Ni}$ & $\mathrm{Cu}$ & $\mathrm{Ni}$ & $\mathrm{Cu}$ & \\
\hline Froth & 31.01 & 0.353 & 0.165 & 48.91 & 62.32 & Xanthate - \\
110 \\
\hline Tailings & 68.99 & 0.166 & 0.045 & 51.09 & 37.68 & $\begin{array}{c}\text { HA - 110 } \\
\text { CuSO }_{4}-30\end{array}$ \\
\hline Feed & 100.00 & 0.224 & 0.082 & 100.00 & 100.00 & \multicolumn{2}{|c}{} \\
\hline
\end{tabular}

Thus, the possibility of using a complexing reagent based on hydroxamic acids as an additional collector instead of the sulfur-containing aeroflot reagent and in the flotation of anthropogenic copper-nickel mineral feeds has been shown.

Magnetic separation of a feed of the original size was carried out using a lab-scale electromagnetic separator SE-138T for dry concentration of weakly magnetic ores. Separation was carried out in stages, feeding the non-magnetic fraction to the subsequent concentration stage with magnetic field strength increasing from 30 to $510 \mathrm{kA} / \mathrm{m}$ (Table 9). Size class $-0.045 \mathrm{~mm}$ was not separated due to its low separation performance using this technology. The yield of this size class was $34 \%$, at a Ni grade of $0.203 \%$ and a $\mathrm{Cu}$ grade of $0.069 \%$. 
Table 9. Dry electromagnetic separation performance.

\begin{tabular}{|c|c|c|c|c|c|c|c|c|}
\hline \multirow{2}{*}{ Product } & \multirow{2}{*}{ Yield, $\%$} & \multicolumn{2}{c|}{ Grade, $\%$} & \multicolumn{2}{c|}{$\begin{array}{c}\text { Circuit } \\
\text { recovery, } \%\end{array}$} & $\begin{array}{c}\text { Plant recovery, } \\
\%\end{array}$ \\
\cline { 2 - 8 } & circuit & plant & $\mathrm{Ni}$ & $\mathrm{Cu}$ & $\mathrm{Ni}$ & $\mathrm{Cu}$ & $\mathrm{Ni}$ & $\mathrm{Cu}$ \\
\hline \multicolumn{8}{|c|}{$\mathbf{N}=\mathbf{3 0} \mathbf{~ k A} / \mathbf{m}$} \\
\hline Magnetic fraction & 59.17 & 39.07 & 0.268 & 0.105 & 72.33 & 71.23 & 48.99 & 50.59 \\
\hline Nonmagnetic fraction & 40.83 & 26.96 & 0.149 & 0.061 & 27.67 & 28.77 & 18.74 & 20.43 \\
\hline Total, EMS & 100.0 & 66.03 & 0.220 & 0.087 & 100.0 & 100.0 & 67.73 & 71.02 \\
\hline \multicolumn{8}{|c|}{$\mathbf{N}=\mathbf{2 6 0} \mathbf{~ k A} / \mathbf{m}$} \\
\hline Magnetic fraction & 78.22 & 51.65 & 0.248 & 0.097 & 88.26 & 86.81 & 59.78 & 61.65 \\
\hline Nonmagnetic fraction & 21.78 & 14.38 & 0.118 & 0.053 & 11.74 & 13.19 & 7.95 & 9.37 \\
\hline Total, EMS & 100.0 & 66.03 & 0.220 & 0.087 & 100.0 & 100.0 & 67.73 & 71.02 \\
\hline \multicolumn{8}{|c|}{$\mathbf{N}=\mathbf{5 1 0} \mathbf{~ k A} / \mathbf{m}$} \\
\hline Magnetic fraction & 95.47 & 63.04 & 0.226 & 0.089 & 98.08 & 97.31 & 66.43 & 69.11 \\
\hline Nonmagnetic fraction & 4.53 & 2.99 & 0.093 & 0.052 & 1.92 & 2.69 & 1.30 & 1.91 \\
\hline Total, EMS & 100.0 & 66.03 & 0.220 & 0.087 & 100.0 & 100.0 & 67.73 & 71.02 \\
\hline
\end{tabular}

An analysis of the separation performance showed that already at a low magnetic field strength, $59 \%$ of the material passes into the magnetic fraction, while when increasing it to 260 and $510 \mathrm{kA} / \mathrm{m}$, the yield of the magnetic fraction is as high as $78 \%$ and $95 \%$, respectively. Despite the fact that the recovery of non-ferrous metals into the magnetic fraction is higher than in the flotation tests, the maximum grade of non-ferrous metals in this fraction is 1.5-2 times lower. These results are due to the fact that the test sample contains highly magnetic magnetite, which is present not only in its unlocked form and as intergrowths with silicates, but also in inclusions in the majority of sulfide intergrowths. Further, some of the pyrrhotite contained in the tailings belongs to its magnetic variety.

The lowest grade of non-ferrous metals in the non-magnetic fraction is observed at a magnetic field strength of $510 \mathrm{kA} / \mathrm{m}$, but at an insignificant yield of this fraction. At higher field strength values, the yield of the product into the nonmagnetic fraction is $14.4 \%$ and $27 \%$ of the ore. Moreover, these fractions are characterized by a lower nickel grade than the flotation tailings.

The use of magnetic separation allows to achieve higher nickel recovery (49-60\%) and relatively low nickel grade of the tailings, but at a lower concentrate grade.

Since the bulk of the sulfides in the feed material is found in intergrowths with magnetite inclusions, it is advisable in this case to use a combination of magnetic and flotation methods, using a magnetic separation process in the head to produce a product with a lower nickel grade than in the flotation tailings. This will also contribute to reduced grinding costs, since the original size feed is sent to magnetic separation. 


\subsubsection{Flotation of the Pechenganickel fresh and mature slags.}

Based on the presented studies of oxidation and changes in the surface properties of sulfides during storage, the following slag processing flow seems promising:

- grinding granules to unlock sulfide inclusions,

- $\quad$ sulfide flotation with selective flocculation of sulfide minerals.

In this connection, flotation tests using fresh slags were conducted. Initial nickel and copper grades were $0.16 \%$ and $0.12 \%$, respectively. Flotation was carried out after fine grinding (to $100 \%$ passing $-40 \mu \mathrm{m}$ ) using the styrene-butadiene copolymer SKS-30 OH (hydrophobic flocculant). Following reagent treatment was chosen: BCs at $200 \mathrm{~g} / \mathrm{t}$, methyl isobutylcarbinol $(\mathrm{MIBC})$ at $100 \mathrm{~g} / \mathrm{t}$. Flotation time $10 \mathrm{~min}$. Following recoveries of valuable components were observed, $\%$ : $\mathrm{Ni}-36.0, \mathrm{Cu}-37.5, \mathrm{Co}-26.4, \mathrm{~S}-26.6$. When grinding the sample to $77 \%$ passing $-40 \mu \mathrm{m}$, the best performance was achieved when using the following reagent treatment: rougher flotation - butyl xanthate $(200 \mathrm{~g} / \mathrm{t}), \mathrm{SKS}-30$ $\mathrm{OH}(20 \mathrm{~g} / \mathrm{t})$, MIBC $70 \mathrm{~g} / \mathrm{t}$; scavenger flotation - butyl xanthate $(100 \mathrm{~g} / \mathrm{t}), \operatorname{MIBC}(35 \mathrm{~g} / \mathrm{t})$.

Following recoveries were observed, \%: $\mathrm{Ni}-32.7, \mathrm{Cu}-30.9, \mathrm{Co}-24.9, \mathrm{~S}-26.8$.

Thus, at this stage, optimal performance could not be achieved.

In order to improve the flotation performance, electric pulse crushing (EPC) of granules in a grinding chamber placed in a tank with process water was tested [114]. The physical basis of the EPC is the explosive action of the plasma channel of the discharge during dielectric breakdown of a solid at a pulsed high voltage. The pulsed current flowing in the discharge channel is accompanied by an abrupt increase in the temperature and pressure of the plasma, which leads to supersonic expansion of the discharge channel, the formation of intense mechanical stresses in the solid, the propagation of cracks and the breakage of the solid. Preliminary preparation of the EPC material, in theory, provides better unlocking of sulfide mineral grains and preserves these from breakage. This is a consequence of the specific physical mechanisms of force loading and crack formation inherent only to this method, which is characterized by high selectivity of breakage [115]. 250 high-voltage pulses of $180 \mathrm{kV}$ were generated and applied with an energy of $640 \mathrm{~J}$.

EPC pretreatment of the slag followed by grinding in an ID-130 grinder significantly improved flotation performance, as shown in Table 10. Slag samples were ground to $100 \%$ passing $-40 \mu \mathrm{m}$. Flotation was carried out on $30 \mathrm{~g}$ charges in a $150 \mathrm{~cm}^{3}$ chamber. The charge was stirred in the chamber at $1500 \mathrm{rpm}$ for $1 \mathrm{~min}$.

After adding BCs, the pulp was stirred for 3 minutes. After adding MIBC, for $1 \mathrm{~min}$. Flotation was carried out at $3500 \mathrm{rpm}$, the froth was collected for 5 minutes. The flotation tailings $\mathrm{pH}$ was 8.27. In the first test, the BCs flow rate was $200 \mathrm{~g} / \mathrm{t}, \mathrm{MIBC} 50 \mathrm{~g} / \mathrm{t}$; in the second -100 and $50 \mathrm{~g} / \mathrm{t}$; in the third -150 and $30 \mathrm{~g} / \mathrm{t}$, respectively. 
Table 10. Flotation performance of $\mathrm{Cu}-\mathrm{Ni}$ slag after EPC.

\begin{tabular}{|c|c|c|c|c|c|c|}
\hline \multirow{2}{*}{ Test \# } & \multirow{2}{*}{ Yield, \% } & \multicolumn{2}{|c|}{ Grade, \% } & \multicolumn{2}{c|}{ Recovery, \% } \\
\cline { 4 - 7 } & Product & & $\mathrm{Ni}$ & $\mathrm{Cu}$ & $\mathrm{Ni}$ & $\mathrm{Cu}$ \\
\hline \multirow{3}{*}{1} & Concentrate & 16.8 & 0.40 & 0.24 & 43.5 & 34.3 \\
\cline { 2 - 7 } & Tailings & 83.2 & 0.10 & 0.09 & 56.5 & 65.7 \\
\cline { 2 - 7 } & Slag & 100.00 & 0.155 & 0.115 & 100.00 & 100.00 \\
\hline \multirow{3}{*}{2} & Concentrate & 35.7 & 0.30 & 0.19 & 67.8 & 56.7 \\
\cline { 2 - 7 } & Tailings & 64.3 & 0.08 & 0.08 & 32.2 & 43.3 \\
\cline { 2 - 7 } & Slag & 100.00 & 0.155 & 0.115 & 100.00 & 100.00 \\
\hline \multirow{3}{*}{$3 *$} & Concentrate & 31.9 & 0.19 & 0.32 & 64.9 & 53.0 \\
\cline { 2 - 7 } & Tailings & 68.1 & 0.08 & 0.08 & 35.1 & 47.0 \\
\cline { 2 - 7 } & Cleaner concentrate & 12.5 & 0.49 & 0.29 & 39.5 & 31.5 \\
\cline { 2 - 7 } & Middlings & 19.4 & 0.21 & 0.13 & 60.5 & 68.5 \\
\cline { 2 - 7 } & Slag & 100.00 & 0.155 & 0.115 & 100.00 & 100.00 \\
\hline
\end{tabular}

* Slag flotation after EPC pretreatment.

3.2. A feasibility study of heap leaching of non-ferrous metals from the naturallyoccurring and anthropogenic sulfide mineral resources of Murmansk Region.

\subsubsection{Leaching of the Allarechensk AD ore.}

The interaction of the $-3+2 \mathrm{~mm}$ ore fraction with the leaching reagent was studied in a dynamic mode in $40 \mathrm{~mm}$ columns at a temperature of $19 \pm 2{ }^{\circ} \mathrm{C}$ for 90 days. The ore fraction contained, \%: $\mathrm{Ni}-0.52, \mathrm{Cu}-0.74, \mathrm{Co}-0.012 .2 \%$ solution of sulfuric acid and the same solution with the addition of an oxidizing agent ( $\mathrm{Fe}^{3+}$ ions) were added as reagents. The ore sample was $150 \mathrm{~g}$, the oxidizing agent flow rate was $80 \mathrm{~g} / \mathrm{t}$. The ore was pre-moisturized. Acid was fed once every 3-4 days at $10 \mathrm{ml}$. At the column output, the solutions were examined by atomic absorption spectrometry.

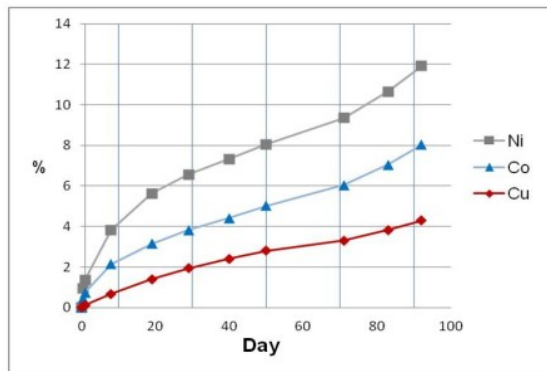

(a)

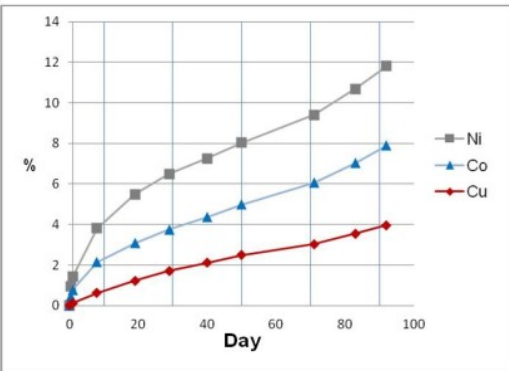

(b)

Figure 17. Leaching kinetics of metals from the Allarechensk AD ore when using a sulfuric acid solution (a) and an acid solution with an oxidizing agent (b). Day 
Figure 17 shows the leaching kinetics of metals from the ore samples. As expected, nickel was leached most intensively. Significantly lower rates were observed for copper. Over 90 days, the recovery of metals during leaching with a solution without an oxidizing agent amounted to, \%: nickel - 11.9, copper - 4.3, cobalt -8.0 ; with an oxidizing agent, $\%$ : nickel - 11.8, copper - 4.0, cobalt - 7.9.

It is noteworthy that adding an oxidizing agent to the solution not only did not lead to an improvement in the recovery of metals, but it even decreased slightly. Probably, the oxidizing agent $\mathrm{Fe}^{3+}$ forms in quantities sufficient to intensify the dissolution of non-ferrous metals. Slow transition of copper into solution is associated with the low dissolution rate of chalcopyrite, which is considered a refractory sulfide [116].

In general, the experiments demonstrated that the ores of the Allarechensk anthropogenic deposit are compatible with heap or tank leaching of non-ferrous metals. Process optimization is needed to intensify the dissolution of sulfide minerals.

\subsubsection{Pechenganickel copper-nickel ore concentration tailings.}

When processing fine-grained anthropogenic or naturally-occurring mineral feeds with a high share of layered hydrosilicates (clay minerals), silting problems arise, leading to a deterioration in the permeability of the pile by leach solutions and stopping the process. These phenomena are observed during storage of copper-nickel ore concentration tailings. The development of chlorites in mature tailings, as well as of mixed-layer formations, with alternation of chlorite and smectite layers, leads to the formation of clay-like engineered soils and a decrease in the filtration coefficient by a factor of more than 100 [106].

One way to solve this problem is to granulate the material using binders. Most often, lime and Portland cement are used as binders. For instance, the results of pilot tests of heap sulfuric acid leaching of the Buribaevo copper-zinc ore concentration tailings are presented in [117]. For the preparation of pellets, quicklime was used in an amount of 5\%. Under laboratory conditions, percolation sulfuric acid leaching of the copper-nickel ore concentration tailings was carried out [118]. As a binder in the preparation of granules, Portland cement in an amount of 3-5\% was used. However, due to the development of sulfoaluminate corrosion of the cement stone, the granules during leaching significantly lost strength and partially collapsed. This limits the possibility of protracted (100 days or longer) industrial applications of the leaching process. At the same time, taking into account the excess of sulfuric acid produced at Kola MMC's sites and the problems arising when trying to sell it, a granular sulfatization process in which sulfuric acid is used as a binder is promising.

Tests were conducted to produce pellets at an S:L ratio of 5-3:1. As a binder, a $10-30 \% \mathrm{H}_{2} \mathrm{SO}_{4}$ solution was used. The diameter of the granules for testing was $0.8-1$ $\mathrm{cm}$. The maximum compressive strength of the granules was 2.8-3 MPa. Further tests were carried out using $10 \%$ acid at an S:L ratio of 3:1 as the binder. 
Percolation leaching was carried out with 1-3\% sulfuric acid solutions in $45 \mathrm{~mm}$ columns for 110 days. Preliminarily, the pellets were saturated with distilled water. The mass of the sample loaded into the column was $150 \mathrm{~g}$. $25 \mathrm{ml}$ of solution was fed once every 3-4 days. Tailings contained, $\%$ : $\mathrm{Ni}-0.17, \mathrm{Cu}-0.07, \mathrm{Co}-0.01$. At the column output, the solutions were examined by atomic absorption spectrometry. The solid phase was investigated by XRD.

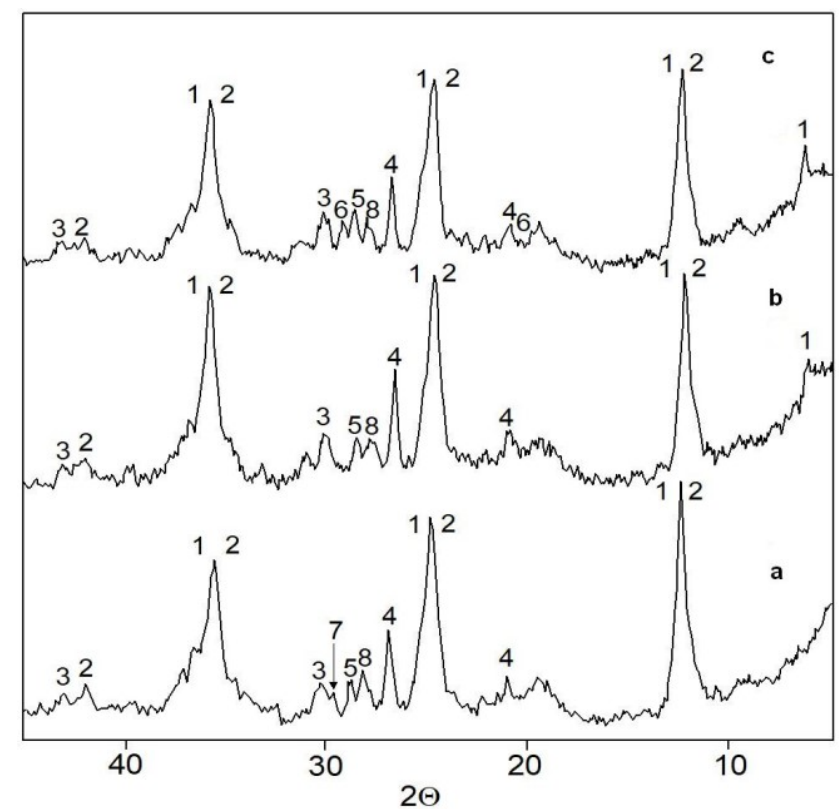

Figure 18. Diffraction pattern fragments of the copper-nickel ore concentration tailings (a); granules after leaching with a $1 \%$ solution of $\mathrm{H}_{2} \mathrm{SO}_{4}$, the top layer of the column (b); the bottom layer (c). Numbers indicate the main reflections of the following minerals: 1 - chlorite; 2 - serpentine; 3 - magnetite; 4 - quartz; 5 - talc; 6 - gypsum; 7 - sulfides (pentlandite, chalcopyrite), 8 - feldspar.

Figure 18 shows the diffraction patterns of the copper-nickel ore concentration tailings, as well as granules from the top and bottom layers of the column, collected at the end of leaching. Serpentines predominate in the composition of the tailings (Figure 18). A quantitative assessment of the content of mineral phases, based on the ratio og the intensities of the main reflections, indicates the presence of magnetite (17\%), quartz (16\%), and feldspars (10\%). Minor amounts of pyroxenes and amphiboles are present $(\sim 3 \%)$. 
Non-ferrous metal sulfides, pentlandite and chalcopyrite, were also identified (shown by arrow in Figure 18a). Differences in the diffraction patterns of granules after leaching consist in the disappearance of sulfide reflections, as well as in an increase in the content of chlorites, especially in the bottom layers of the column (Figure $18 \mathrm{~b}, \mathrm{c}$ ). Unidentified phases appear. In addition, coating formed on the granules in the top layer of the column was analyzed. It is a mixture of sulfate phases - white translucent hexahydrite $\mathrm{MgSO}$ ${ }_{4} 6 \mathrm{H}_{2} \mathrm{O}$, colorless epsomite $\mathrm{MgSO}_{4} 7 \mathrm{H}_{2} \mathrm{O}$, in which magnesium can be partially isomorphically substituted by iron, nickel and cobalt, as well as gypsum $\mathrm{CaSO}_{4} 2 \mathrm{H}_{2} \mathrm{O}$, forming rounded aggregates of needle-shaped crystals. All this indicates the interaction with the sulfate solution of not only sulfide minerals, but also silicates, primarily serpentine. At the same time, chemically inert quartz, feldspar, and magnetite practically did not dissolve during the experiments, their relative content in the granules in the bottom layer did not change, while in the top layer it increased.
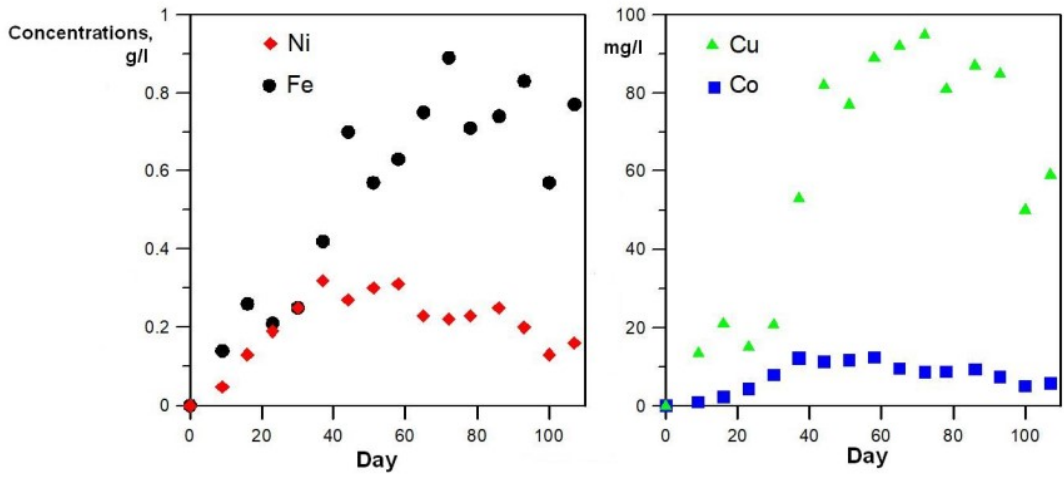

Figure 19. Concentrations of metals in pregnant solutions during the leaching of granulated copper-nickel ore concentration tailings.

The leaching dynamics of metals in the experiment is shown in Figure 19. The process is quite intense. Nickel concentrations in the solution are stable and are in the range of 0.1$0.35 \mathrm{~g} / \mathrm{l}$. These indicators are acceptable for the industrial implementation of the method if the process solutions are recycled. Taking into account the dissolution of part of silicate minerals, iron concentrations reach $0.9 \mathrm{~g} / \mathrm{l}$. Thus, methods need to be developed for the selective removal of iron from pregnant solutions. A relatively high concentration of copper is noteworthy. Cobalt performance is also quite stable.

Figure 20 shows the leaching kinetics of metals from the granulated copper-nickel ore concentration tailings. As expected, nickel was leached most intensively. Over 110 days, about $60 \%$ of the meta in the granules passed into the solution. Copper's lower 
performance ( $44 \%$ ) is explained by the fact that the metal is present in the composition of chalcopyrite. The relatively low performance of cobalt $(\sim 41 \%)$ is probably associated with the presence of some of the metal in the form of an isomorphic impurity in magnetite.

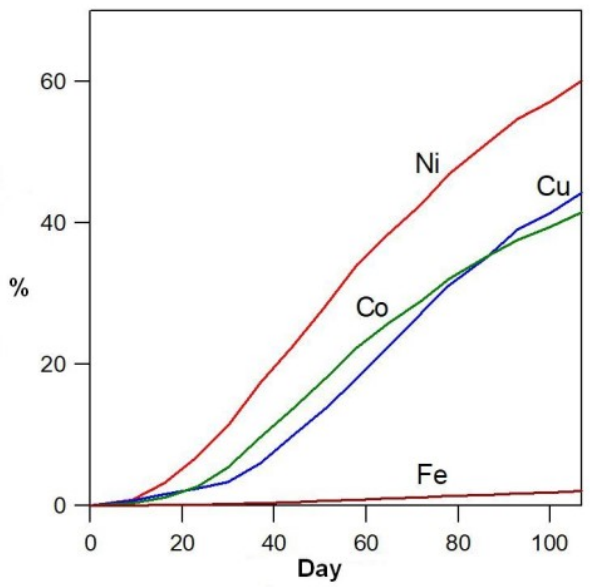

Figure 20. Leaching kinetics of metals from the granulated copper-nickel ore concentration tailings.

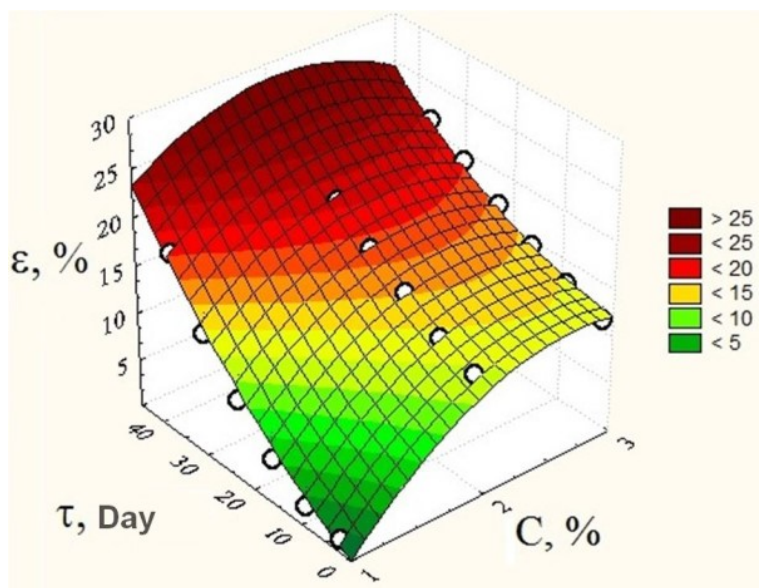

Figure 21. Effect of leach reagent concentration $(C)$ and leach time $(\tau)$ on nickel recovery $(\varepsilon)$ from concentration tailings. 
At the next stage, the effect of acid concentration on the recovery kinetics of nonferrous metals in the percolation leaching mode was investigated. $1 \%, 2 \%$, and $3 \%$ sulfuric acid solutions were used. The tests were carried out for 45 days. The highest metal recovery was achieved using 3\% sulfuric acid. As an example, Figure 21 shows the kinetics of nickel recovery.

\subsubsection{Leaching of the Pechenganickel pre-granulated slags.}

Due to the fact that non-ferrous sulfides in the slag are found inside the silicate matrix, for better access of the leaching reagent to minerals, it is necessary to grind the granules and then pelletize the ground slag in agglomerators.

Experiments were carried out to produce pellets from the slag ground to $-40 \mu \mathrm{m}$ at an S:L ratio of 5-3: 1 . As a binder, a $10 \% \mathrm{H}_{2} \mathrm{SO}_{4}$ solution was used. The diameter of the pellets for testing was $0.8-1 \mathrm{~cm}$, their compressive strength was 2.3-2.5 MPa. Percolation leaching was carried out with $1-3 \%$ sulfuric acid solutions in $45 \mathrm{~mm}$ columns for 110 days. Preliminarily, the pellets were saturated with distilled water. The mass of the sample loaded into the column was $150 \mathrm{~g} .25 \mathrm{ml}$ of solution was fed once every 3-4 days. The feed slag contained, $\%$ : $\mathrm{Ni}-0.155, \mathrm{Cu}-0.115, \mathrm{Co}-0.09$.

At the column output, the solutions were examined by atomic absorption spectrometry. The solid phase was examined by $\mathrm{x}$-ray phase analysis (XRD).

According to the XRD data, the total content of the crystalline phase in the pellet samples is low (Figure 22). Halo in the area of angles $2 \Theta 20-40^{\circ}$ indicates the presence of a glass phase. X-ray examination of a single grain from the coat on the surface of the pellets identified hexahydrite $\mathrm{MgSO}_{4} \cdot 6 \mathrm{H}_{2} \mathrm{O}$ represented by white translucent icy aggregates and transparent grains of a wattvilleite isostructural phase $\mathrm{Na}_{2} \mathrm{Ca}\left(\mathrm{SO}_{4}\right)_{2} 4 \mathrm{H}_{2} \mathrm{O}$.

The $\mathrm{pH}$ values of the solutions after interaction with the slag remained quite stable throughout the experiments (Figure 23). The first point in the graphs indicates the saturation of the pellets with water.

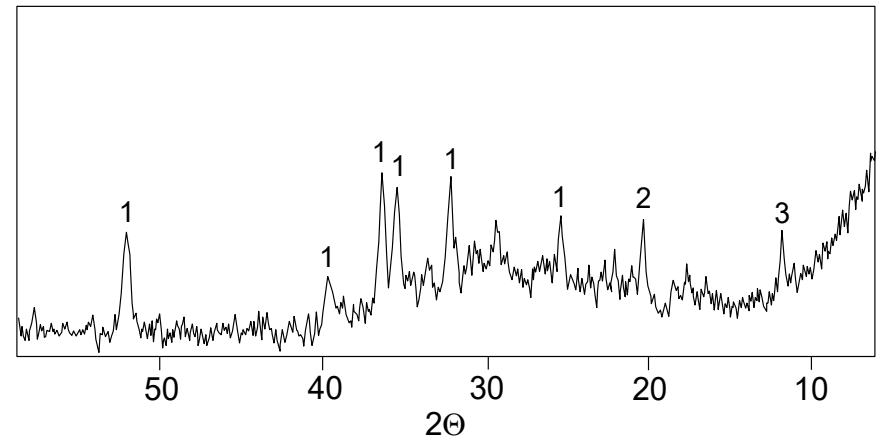

Figure 22. Diffraction pattern of the pellet after leaching. The numbers indicate the main reflections of minerals: 1 - olivine; 2 - hexahydrite; 3 - unidentified phase. 
Metal concentrations in the pregnant solutions during the experiment are shown in Figure 24a. The performance is generally acceptable for the commercialization of the method, provided it is further improved by recycling the solutions and intensifying leaching using oxidizing agents. Figure $24 \mathrm{~b}$ shows the leaching kinetics of metals from the pellets. As expected, nickel was leached most intensively. After 107 days, about $17 \%$ of the metal passed into the solution. For cobalt, the figure was $8.6 \%$. Copper leached significantly less effectively $(\sim 4.6 \%)$.

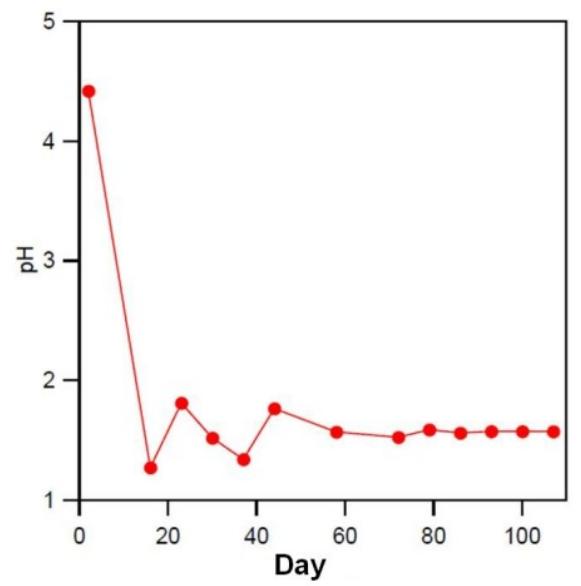

Figure 23. Change in the $\mathrm{pH}$ values of the solutions after interaction with the slag. Time, days

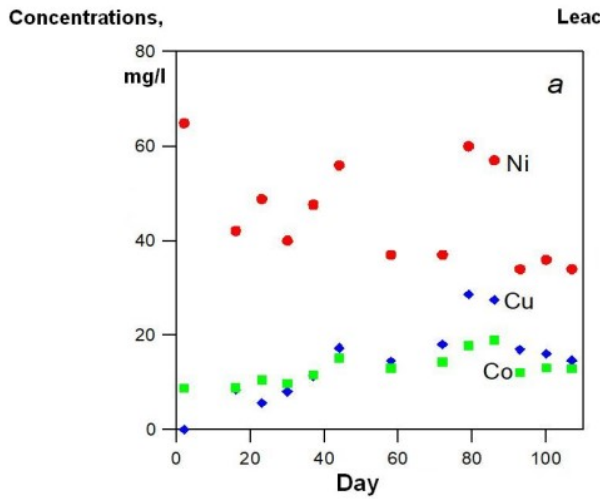

eaching

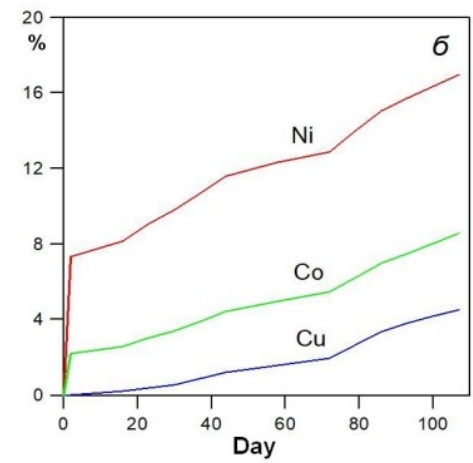

Figure 24. Metal concentrations in the leaching solutions and process kinetics. 


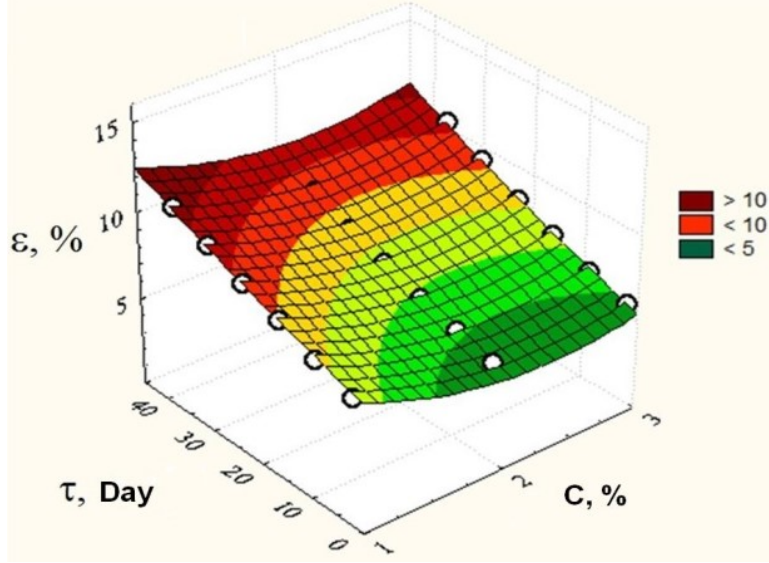

Figure 25. Effect of leach reagent concentration $(C)$ and leach time $(\tau)$ on nickel recovery $(\varepsilon)$ from slags.

Similarly, to the concentration tailings, the effect of acid concentration on the recovery kinetics of non-ferrous metals in the percolation leaching mode was investigated. $1 \%, 2 \%$, and 3\% sulfuric acid solutions were used. The tests were carried out for 45 days. Nickel and copper leaching performed best when treated with a 3\% solution of sulfuric acid. Cobalt had similar recovery from the slags in all treatments. As an example, Figure 25 shows the kinetics of nickel recovery. No significant improvement in performance was achieved. Thus, similarly to the concentration tailings, from an economic point of view it is advisable to add a $1 \%$ solution of sulfuric acid as a leaching reagent.

\section{Conclusion}

Based on a study of the mineral and material compositions of copper-nickel ore and concentration tailings, it was found that this mineral feed is promising for processing. The examined sites are exposed to hypergene alteration, which in the case of the Allarechensk anthropogenic deposit, reduces the grade of the mineral feed due to an increase in the proportion of oxidized ores.

The possibility of flotation recovery of non-ferrous metals from the concentration tailings of copper-nickel ores was investigated. The feasibility was shown of using a combination of magnetic and flotation methods with a magnetic separation process in the head to obtain a product with a lower nickel content than in flotation tailings. This will also contribute to additional economic benefits through reduced grinding costs, since the original size feed is sent to magnetic separation. 
A flotation study of granulated copper-nickel slags was carried out. It was found that slag pretreatment by electropulse crushing with subsequent grinding to $100 \%$ passing -40 microns makes it possible to increase the recovery of non-ferrous metals into concentrate by $14-20 \%$. This mineral feed preparation method provides better unlocking of sulfide mineral grains and preserves these from breakage.

The recovery of metals as a result of 90 days' leaching of the Allarechensk AD ore irrigated with an oxidizing agent-free solution amounted to, \%: nickel - 11.9, copper - 4.3, cobalt - 8.0; with an oxidizing agent, \%: nickel - 11.8, copper - 4.0, cobalt - 7.9. In addition, thionic acidophilic iron and sulfur oxidizing bacteria were found in the water samples collected near the open pit and in the ores, which indicates the possibility of using microorganisms in the process of heap leaching.

Percolation leaching of agglomerated copper-nickel ore concentration tailings and slags with $1-3 \%$ sulfuric acid solutions made it possible to recover from the tailings more than $60 \%$ of nickel after 110 days when using a $1 \%$ solution. The daily leaching rates of metals from the tailings were, \%: nickel -0.55 , cobalt -0.37 , copper -0.40 . From the slags, $\%$ : nickel -0.16 , cobalt -0.08 , copper -0.05 . Over the same period, about $17 \%$ of nickel was recovered from the copper-nickel slags.

Thus, the theoretical possibility of processing the cut-off grade copper-nickel minerals of Murmansk Region was shown. Process conditions were found making the process economically feasible. Processing these mineral feed types will also allow in the long term to improve the environmental situation in the region.

\section{References}

1. Chanturia, V. A. Innovative technology for the processing of anthropogenic mineral resources / V. A. Chanturia, V. E. Wigderhaus // Mining Journal. - 2008. No. 6. - Pp. 71-74. [In Russian].

2. Integrated sustainable waste management. Mining industry: textbook / V.I. Petukhov et al.; ed. by V.I. Petukhov. - Moscow: Publishing House of the Academy of Natural Sciences, 2016. - 638 p. [In Russian].

3. Aksenov, E. M. Anthropogenic deposits: development problems and prospects / E. M. Aksenov, R. K. Sadykov, V. A. Aliskerov, Yu. A. Kiperman, M. A. Komarov // Exploration and Conservation of Mineral Resources. — 2010. — No. 2. - Pp. 17-20. [In Russian].

4. Bykhovsky, L.Z. Industrial waste as a resource for expanding the mineral resource base: state of the art and development problems / L.Z. Bykhovsky, L.V. Sporykhina // Mineral Resources of Russia. — 2011. - No. 4. - Pp. 15-20. [In Russian].

5. Report on the State and Protection of the Environment in Murmansk Region in 2018 [electronic version] / Ministry of Natural Resources and Environment of Murmansk Region, 2019. Available at: https://gov-murman.ru/region/environmentstate. [In Russian]. 
6. Masloboev, V. A. Assessment of the environmental hazard of the storage of copper-nickel ore mining and processing waste / V. A. Masloboev, S. G. Seleznev, D. V. Makarov, A. V. Svetlov // FTPRPI. — 2014. — No. 3. — Pp. 138-153. [in Russian].

7. Emlin, E.F. Technogenesis of the pyrite deposits of the Urals / E.F. Emlin. Sverdlovsk: UGU, 1991. 256 p. [In Russian].

8. Zosin, A.P. Ecological aspects of the processes of geochemical transformation of the mineral waste of sulfide copper-nickel ore processing / A.P. Zosin, T.I. Priymak, L. B. Koshkina, V.A. Masloboev // Environmental Chemistry. — 2003. No. 1. — Pp. 3442. [in Russian].

9. Doyle, F. M. Acid mine drainage from sulphide ore deposits / F. M. Doyle // Sulphide deposits - their origin and processing. Inst. Mining and Metallurgy. - 1990. P. 301-310.

10. Moncur, M. C. Mine drainage from the weathering of sulfide minerals and magnetite / M. C. Moncur, J. L. Jambor, C. J. Ptacek, D. W. Blowes // Applied Geochemistry. - 2009. - V.24. - P. 2362-2373.

11. Moncur, M. C. Seasonal cycling and mass-loading of dissolved metals and sulfate discharging from an abandoned mine site in northern Canada / M. C. Moncur, C. J Ptacek., M. Hayashi, D. W. Blowes, S. J. Birks // Applied Geochemistry - 2014. - 41. - P. 176188.

12. Chanturia V.A. New processes for comprehensive recovery of valuable components from mineral feeds: state of the art and principal directions of development / V.A. Chanturia // Geology of Ore Deposits. — 2007. — Vol. 49. — No. 3. - Pp. 235242. [In Russian].

13. Chanturia, V. A. Developing the physical and chemical foundations and innovative technologies for the deep processing of anthropogenic minerals / V. A. Chanturia, A. P. Kozlov // Mining Journal. — 2014. — No. 7. — Pp. 79-84. [In Russian].

14. Halezov, B.D. Copper and copper-zinc ore heap leaching; Ural Branch of Russian Academy of Sciences: Ekaterinburg, Russia, 2013; p. 360. (In Russian).

15. Watling, H.R. The bioleaching of sulphide minerals with emphasis on copper sulphides - A review. Hydrometallurgy. 2006, 84, 81-100.

16. Watling, H.R. The bioleaching of nickel sulphides. Hydrometallurgy. 2008, 91, 70-88.

17. Snurnikov A.P. Integrated processing of mineral resources in non-ferrous metallurgy. / A.P. Snurnikov — Moscow: Metallurgy, 1986. — 384 p. [In Russian].

18. Chanturia, V. A. Innovative technologies and processes for the recovery of valuable components from unconventional, refractory, and anthropogenic mineral resources / V. A. Chanturia, A. P. Kozlov, T. N. Matveeva, A. A. Lavrinenko // FTPRPI. - 2012. — No. 5. — Pp. 144-156. [in Russian]. 
19. Chanturia, V. A. Resource-saving technology for the processing of minerals and environmental protection / V. A. Chanturia, N. N. Chaplygin, V. E. Wigderhaus // Mining Journal. — 2007. — No. 2. — Pp. 91-96. [in Russian].

20. Golovko, E.A.; Rozental, A.K.; Sedel'nikov, V.A.; Suhodrev, V.M. Chemical and bacterial leaching of copper-nickel ores. Nauka: Leningrad, Russia, 1978; p. 199. (In Russian).

21. Mazukhina, S. I. Modeling copper precipitation in physicochemical geotechnologies / S. I. Mazukhina, D. V. Makarov, A. V. Svetlov, V. A. Masloboev // 8th Russian National Fersman Scientific Conference "Mineralogy, Petrology, and Minerals of the Kola Region,” Apatity. — 2011. - Pp. 264-268. [In Russian].

22. Makarov, D. V. Applications of geochemical barriers in wastewater treatment and non-ferrous metals recovery processes / D. V. Makarov, V. A. Masloboev, D. P. Nesterov, A. V. Svetlov, Yu. P. Menshikov, E A. Korneva, Yu. L. Bayurova // Industrial Ecology. - 2012. — No. 2. - Pp. 43-46. [In Russian].

23. Seleznev, S. G. Mining waste dumps of Allarechensk sulphidic copper-nickel deposit as a novel geological and process type of anthropogenic mineral resources. / S. G. Seleznev, N. A. Stepanov // University Bulletin. Mining Journal. — 2011. — No. 5. — Pp. 32-40. [In Russian].

24. Marescotti, P. Mineralogical and chemical evolution of ochreous precipitates from the Libiola $\mathrm{Fe}-\mathrm{Cu}$-sulfide mine (Eastern Liguria, Italy) / P. Marescotti, C. Carbone, P. Comodi, F. Frondini, G. Lucchetti // Applied Geochemistry. - 2012. - №. 27. - P. $577-$ 589.

25. Svetlov, A. Heap leaching and perspectives of bioleaching technology for the processing of low-grade copper-nickel sulfide ores in Murmansk region, Russia / A. Svetlov, D. Makarov, E. Selivanova, V. Masloboev, D. Nesterov // Journal of the Polish Mineral Engineering Society (Inzynieria Mineralna). - 2017. - No 1 (39) - P. 51-57.

26. Svetlov, A. Perspectives for heap leaching of non-ferrous metals (Murmansk Region, Russia) / A. Svetlov, E. Kravchenko, E. Selivanova, E. Seleznev, D. Nesterov, D. Makarov, V. Masloboev // Journal of the Polish Mineral Engineering Society (Inzynieria Mineralna). - 2015. - N2(36). - P. 231-236.

27. Rakayev, A.I. Mineralogical and process studies of low-grade serpentinite copper-nickel ores of the Pechenga ore field / A.I. Rakayev, Yu. N. Neradovskiy, E.V. Chernousenko, T.A. Morozova // Bulletin of the Murmansk State Technical University. - 2009. — Vol. 12. — No. 4. — Pp. 632-637. [In Russian].

28. Rakayev, A.I. Applications of preconcentration methods for further recovery of valuable components from the tailings dumps of the Allarechensk deposit / A.I. Rakayev, E.V. Chernousenko // Arctic Industry. — 2007. — No. 2. — Pp. 62-63. [In Russian].

29. Rudnev, B.P. A review of the global processing practice of the metals industry tailings by concentration methods / Rudnev B.P. // Non-Ferrous Metallurgy. — 2009. No. 4. - Pp. 3-9. [In Russian]. 
30. Rudnev, B.P. Developing a process for the preconcentration of valuable components from tailings during hydrotransportation / Rudnev B.P. // Non-Ferrous Metallurgy. - 2009. - No. 6. - Pp. 3-22. [In Russian].

31. Chanturia, V.A. Progressive (environmentally-friendly) processing technology for copper-zinc anthropogenic minerals: challenges and solutions / V. A. Chanturia, V. E. Wigdergauz, E. A. Schrader, et al. // Engineering Ecology. — 2004. — No. 5. Pp. 3-11. [In Russian].

32. Chaynikov, V.V. Practice of using anthropogenic resources of ferrous and nonferrous metals industry in Russia and abroad / V.V. Chaynikov, L. A. Kryuchkova Moscow, 1994. - 30 p. [In Russian].

33. Arslan, C. Recovery of copper, cobalt, and zinc from copper smelter and converter slags / C. Arslan, F. Arslan // Hydrometallurgy. - 2002. - V.67. - P. 1-7.

34. Rao, G. V. Flotation of copper from converter slags / G. V. Rao, B. D. Nayak // Journal of Mines, Metals and Fuels. - 1992. - V.40. - N3-4. - P. 131-134.

35. Shen, H. An overview of recovery of metals from slags / H. Shen, E. Forssberg // Waste Management. - 2003. - V.23. - P. 933-949.

36. Sukla, L. B. Recovery of cobalt, nickel, and copper from converter slag through roasting with ammonium sulphate and sulfuric acid / L. B. Sukla, S. C. Panda, P. K. Jean // Hydrometallurgy. - 1986. - V.16. - P. 153-165.

37. Kotelnikova, A. L. Concerning the rational management of copper smelting slag processing / A. L. Kotelnikova, I. F. Ryabin, G. G. Korinevskaya, B. D. Khalezov, D. S. Reutov, V. A. Muftakhov // Mineral Resource Base and Exploration. — 2014. No. 12. - Pp. 14-19. [In Russian].

38. Makarov, D. V. A study of the possibility of recovery of non-ferrous metals from anthropogenic copper-nickel products / D. V. Makarov, V. A. Masloboev, D. P. Nesterov, Yu. P. Menshikov, A. V. Svetlov, I. V. Bocharova // New Concentration and Integrated Processing Technology Naturally-Occurring and Anthropogenic Minerals (Plaksinsky readings). - 2011. - Pp. 389-392. [In Russian].

39. Sabanova, M.N. Flotation of copper slag in a concentrator closed water cycle / M.N. Sabanova, I.V. Shadrunova, N.N. Orekhova, O.E. Gorlova // Non-Ferrous Metals. - 2014. - No. 10. - Pp. 16-24. [In Russian].

40. Gurevich, B. I. Geopolymer binder based on mechanically activated compositions of magnesia-iron slag and nepheline / B. I. Gurevich, A. M. Kalinkin, E. V. Kalinkina, S. I. Mazukhina, V. V. Tyukavkina // Prospective Materials. — 2015. — No. 3. — Pp. 6371. [In Russian].

41. Makarov, V.N. Construction and industrial materials based on the minerals of the Kola Peninsula / V.N. Makarov, O. N. Krasheninnikov, B. I. Gurevich, et al. - Apatity: KRC RAS, Part 1, 2. 2003. - 430 p. [In Russian].

42. Metallurgical slags of Moncha and Pechenga / Ed. by D. D. Tenner. - Moscow, Leningrad: Nauka, 1965. — 203 pp. [In Russian]. 
43. Rossinsky, E. E. Metallurgical slag of the copper-nickel industry of the Arctic / E. E. Rossinsky — Leningrad: Nauka, 1974. — 284 pp. [In Russian].

44. Kalinnikov, V. T. Applications of non-ferrous metallurgy slags in the manufacture of glasses, glass crystalline materials, and mineral fiber / V. T. Kalinnikov, V. N. Makarov, O. V. Suvorova, D. V. Makarov, A. I. Zakharchenko, I. V. Makarova // Chemical Technology. — 2002. - No. 7. — Pp. 6-10. [In Russian].

45. Zosin, A.P. Adsorbents based on magnesia-ferrous slag of non-ferrous metallurgy for the removal of non-ferrous metakl cations from process effluents / A. P. Zosin, T. I. Priymak, L.B . Koshkina, V. A. Masloboev // Murmansk State Technical University Bulletin. — 2008. - Vol. 11. - No. 3. - Pp. 502-505. [In Russian].

46. Kasikov, A. G. A feasibility assessment of using the processing waste of Kola MMC dumped slags as a component of binding materials / A. G. Kasikov, B. I. Gurevich, V. V. Tyukavkina, E. A. Okorochkova // Arctic Industry. — 2008. — No. 7-8. — Pp. 5-7. [In Russian].

47. Okorochkova, E. A. Effect of the leaching conditions of Pechenganickel slag on the recovery of non-ferrous metals and the behavior of silicon dioxide / E. A. Okorochkova // Research and practical problems of chemistry and technology for the integrated management of the mineral resources of the Kola Peninsula. Apatity: KRC RAS - 2007. - Pp. 131-135. [In Russian].

48. Khalezov, B. D. Historical background and review of the world practice of heap and underground leaching / B. D. Khalezov, N. A. Vatolin, V. A. Nezhivykh, A. Yu. Tvyakov // GIAB MGGU. — 2002. — No. 4. — Pp. 139-143. [In Russian].

49. Polkin, S.I. Bacterial leaching technology for non-ferrous and rare metals / S.I. Polkin, E.V. Adamov, V.V. Panin — Moscow: Nedra, 1982. — 288 p. [In Russian].

50. Kashuba, S.G.; Leskov, M.I. Heap leaching in the Russian practice - an overview of the experience and analysis of prospects. Zoloto i tehnologii. 2014, 1(23), 10-14. (In Russian).

51. Svetlov, A.V.; Makarov, D.V.; Goryachev, A.A. Directions for intensification of leaching of non-ferrous metals on the example of low-grade copper-nickel ore deposits in the Murmansk region. In Proceedings of Mineralogy of technogenesis - 2017. Institute of Mineralogy, Ural Branch of RAS: Miass, Russia, 2017; pp.154-162. (In Russian).

52. Svetlov, A.V. Possibilities of bioleaching of substandard sulfide ores of nonferrous metals, promising sites in Murmansk Region / A.V. Svetlov, D.V. Makarov // Mineralogy of Technogenesis-2016. — Pp. 83-98. [In Russian].

53. Trubetskoy, K. N. Problems and prospects for the development of resourcesaving and resource-reproducing geotechnologies for the integrated development of mineral resources. Mineral extraction technology / K. N. Trubetskoy, D. R. Kaplunov, M. V. Rylnikova // FTPRPI. - 2012. — No. 4. - Pp. 116-124. [In Russian].

54. Petersen, J. Heap leaching as a key technology for recovery of values from lowgrade ores - A brief overview. Hydrometallurgy. 2016, 165, 206-212. 
55. Karavaiko, G.I.; Rossi, Dzh.; Agate, A.; Grudev, S.; Avakyan, Z.A. Biogeotechnology of metals: Practical guide; Tsentr mezhdunarodnykh proektov GKNT: Moscow, Russia, 1989; p. 375. (In Russian).

56. Kondrat'eva, T.F.; Bulaev, A.G.; Muravyov, M.I. Microorganisms in biotechnologies of sulfide ores processing. Nauka: Moscow, Russia, 2015; p. 212. (In Russian)

57. Watling, H.R. Review of biohydrometallurgical metals extraction from polymetallic mineral resources. Minerals. 2015, 5, 1-60.

58. Dement'ev, V.E., Druzhinina, G.E., Gudkov, S.S. Heap leaching of gold and silver. Irgiredmet: Irkutsk, Russia, 2004; p. 252. (In Russian).

59. Sovmen, V.K.; Gus'kov, V.N.; Belyi, A.V.; Kuzina, Z.P.; Drozdov, S.V.; Savushkina, S.I.; Maiorov, A.M.; Zakraevskii, M.P. Processing of gold-bearing ores with the use of bacterial oxidation in the conditions of Far North. Nauka: Novosibirsk, Russia, 2007; p. 144. (In Russian).

60. Golik, V.I.; Zaalishvili, V.B.; Razorenov, Yu.I. Uranium leaching experience. Mining informational and analytical bulletin. 2014, 7, 97-103.

61. Anjum, F.; Shahid, M.; Akcil, A. Biohydrometallurgy techniques of low grade ores: A review on black shale. Hydrometallurgy. 2012, 117-118, 1-12.

62. Watling, H.R.; Elliot, A.D.; Maley, M.; van Bronswijk, W.; Hunter, C. Leaching of a low-grade, copper-nickel sulfide ore. 1 . Key parameters impacting on $\mathrm{Cu}$ recovery during column bioleaching. Hydrometallurgy. 2009, 97, 204-212.

63. Maley, M.; van Bronswijk, W.; Watling, H.R. Leaching of a low-grade, coppernickel sulfide ore 2 . Impact of aeration and $\mathrm{pH}$ on $\mathrm{Cu}$ recovery during abiotic leaching. Hydrometallurgy. 2009, 98, 66-72.

64. Maley, M.; van Bronswijk, W.; Watling, H.R. Leaching of a low-grade, coppernickel sulfide ore 3. Interactions of $\mathrm{Cu}$ with selected sulfide minerals. Hydrometallurgy. 2009, 98, 73-80.

65. Halinen, A-K.; Rahunen, N.; Kaksonen, A.H.; Puhakka, J.A. Heap bioleaching of a complex sulfide ore: Part I. Effect of temperature on base metal extraction and bacterial compositions. Hydrometallurgy. 2009, 98, 92-100.

66. Halinen, A-K.; Rahunen, N.; Kaksonen, A.H.; Puhakka, J.A. Heap bioleaching of a complex sulfide ore: Part II. Effect of temperature on base metal extraction and bacterial compositions. Hydrometallurgy. 2009, 98, 101-107.

67. Qin, W.; Zhen, S.; Yan, Z.; Campbell, M.; Wang, J.; Liu, K.; Zhang, Y. Heap bioleaching of a low-grade nickel-bearing sulfide ore containing high levels of magnesium as olivine, chlorite and antigorite. Hydrometallurgy. 2009, 98, 58-65.

68. Zhen, S.; Yan, Z.; Zhang, Y.; Wang, J.; Campbell, M.; Qin, W. Column bioleaching of a low grade nickel-bearing sulfide ore containing high magnesium as olivine, chlorite and antigorite. Hydrometallurgy. 2009, 96, 337-341. 
69. Yang, C.; Qin, W.; Lai, S.; Wang, J.; Zhang, Y.; Jiao, F.; Ren, L.; Zhuang, T.; Chang, Z. Bioleaching of a low grade nickel-copper-cobalt sulfide ore. Hydrometallurgy. 2011, 106, 32-37.

70. Bhatti, T.M.; Bigham, J.M.; Vuorinen, A.; Tuovinen, O.H. Chemical and bacterial leaching of metals from black schist sulfide minerals in shake flasks. International Journal of Mineral Processing. 2012, 110-111, 25-29.

71. Mandziak, T.; Pattinson, D. Experience-based approach to successful heap leach pad design. Mining World. 2015, 12, 5, 28-35.

72. Petersen, J.; Dixon, D.G. Modelling zinc heap bioleaching. Hydrometallurgy. 2007, 85, 127-143.

73. Mellado, M.E.; Galvez, E.D.; Cisternas, L.A.; Ordonez, J. A posteriori analysis of analytical models for heap leaching. Minerals \& Metallurgical Processing. 2012, 29, $103-112$.

74. Ding, D.; Song, J.; Ye, Y.; Li, G.; Fu, H.; Hu, N.; Wang, Y. A kinetic model for heap leaching of uranium ore considering variation of model parameters with depth of heap. Journal of Radioanalytical and Nuclear Chemistry. 2013, 298, 1477-1482.

75. McBride, D.; Gebhardt, J.E.; Croft, T.N.; Cross, M. Modeling the hydrodynamics of heap leaching in sub-zero temperatures. Minerals Engineering, 2016, 90, 77-88.

76. Lodeyschikov, V.V. Processing of nickel ores by heap leaching bacteria. The experience of the Finnish company Talvivaara. Zolotodobyicha. 2009, 132, 12-14. (In Russian).

77. Sinha, K.P.; Smith, M.E. Cold climate heap leaching. In Proceedings of the 3rd International Conference on Heap Leach Solutions. Published by InfoMine Inc.; 2015. pp. 409-425.

78. Smith, K.E. Cold weather gold heap leaching operational methods. Journal of the Minerals, Metals, and Materials Society. 1997, 49, 20-23.

79. Shesternev, D.M.; Myazin, V.P.; Bayanov, A.E. Heap gold leaching in permafrost zone in Russia. Gornyi Zhurnal (Mining Journal). 2015, 1, 49-54. (In Russian).

80. Ptitsyn, A.B. Geochemical fundamentals of metal geotechnology in permafrost conditions. Nauka: Novosibirsk, Russia, 1992; p. 120. (In Russian).

81. Ptitsyn, A.B.; Sysoeva, E.I. Cryogenic mechanism of the Udokan oxidizing area formation // Russian Geology and Geophysics. 1995, 36, 90-97.

82. Abramova, V.A.; Ptitsyn, A.B.; Markovich, T.I.; Pavlyukova, V.A.; Epova, E.S. Geochemistry of Oxidation in Permafrost Zones. Nauka: Novosibirsk, Russia, 2009; p. 88. (In Russian).

83. Yurgenson, G.A. The cryomineralogenesis of minerals in the technological massifs. In Proceedings of Mineralogy of technogenesis - 2009. Institute of Mineralogy, Ural Branch of RAS: Miass, Russia, 2009; pp. 61-75. (In Russian). 
84. Markovich, T.I. Processes of heavy metal sulphides oxidation with nitrous acid. Abstract of PhD thesis. Novosibirsk, 1999. 23 p. (In Russian)

85. Ptitsyn, A.B.; Markovich, T.I.; Pavlyukova, V.A.; Epova, E.S. Modeling cryogeochemical processes in the oxidation zone of sulfide deposits with the participation of oxygen-bearing nitrogen compounds. Geochemistry International. 2007, 45, 726-731.

86. Abramova, V.A.; Parshin, A.V.; Budyak, A.E. Physical and chemical modeling of the influence of nitrogen compounds on the course of geochemical processes in the cryolithozone. Kriosfera Zemli. 2015, 9, 32-37. (In Russian)

87. Abramova, V.A.; Parshin, A.V.; Budyak, A.E.; Ptitsyn, A.B. Geoinformation modeling of sulfide frost weathering in the area of Udokan deposit. Journal of Mining Science. 2017, 53, 501-597.

88. Khalezov, B.D. Problems of Udokansky field ores processing. Mining informational and analytical bulletin. 2014, 8, 103-108. (In Russian).

89. Riekkola-Vanhanen, M. Talvivaara black schist bioheapleaching demonstration plant. Advanced Materials Research. 2007, 20-21, 30-33.

90. Puhakka, J.A.; Kaksonen, A.H.; Riekkola-Vanhanen, M. Heap leaching of black schist. In Biomining; Rawlings, D.E., Johnson, D.B., Eds.; Springer-Verlag: Berlin, Germany, 2007; pp. 139-151.

91. Halinen, A.-K.; Rahunen, N.; Määttä, K., Kaksonen, A.H., Riekkola-Vanhanen, M., Puhakka, J. Microbial community of Talvivaara demonstration bioheap. Advanced Materials Research. 2007, 20-21, 579.

92. Riekkola-Vanhanen, M. Talvivaara Sotkamo mine - Bioleaching of a polymetallic nickel ore in subarctic climate. Nova Biotechnologica. 2010, 10-1, 7-14.

93. Riekkola-Vanhanen, M.; Palmu, L. Talvivaara Nickel Mine - from a project to a mine and beyond. In Proceedings of symposium Ni-Co 2013; Battle, T., Moats, M., Cocalia, V. et al., Eds.; Springer International Publishers: Switzerland, 2016; pp. 269-278.

94. Annual Report TALVIVAARA. 2013. 178 p.

95. Lyalikova, N.N. Bacteria role in the sulfide ores oxidizing of the copper-nickel deposits on the Kola Peninsula. Microbiology. 1961, 30, 135-139. (In Russian).

96. Karavaiko, G.I.; Kuznetsov, S.I.; Golomzik, A.I. Role of microorganisms in leaching metals from ores. Nauka: Moscow, Russia, 1972; p. 248. (In Russian).

97. Seleznev, S.G. Nontraditional efficient ways of sulfide copper-nickel ores enrichment: the case of the Allarechensk man-caused deposit. Izvestija VUZov. Gorny Zhurnal. 2011, 8, 118-125. (In Russian).

98. Boltyrov, V.B.; Seleznev, S.G.; Storozhenko, L.A. Optimum compromise of the methods for sulfide copper-nickel ores enrichment of the man-caused object "The Allarechensk deposit dumps". International Scientific-Research Magazine. 2015, 11(42), Part 3, 113-117. (In Russian). 
99. Svetlov, A.; Seleznev, S.; Makarov, D.; Selivanova, E.; Masloboev, V.; Nesterov, D. Heap leaching and perspectives of bioleaching technology for the processing of lowgrade copper-nickel sulfide ores in the Murmansk region, Russia. Journal of the Polish Mineral Engineering Society (Inzynieria Mineralna). 2017, 39, 51-59.

100. Fokina, N.V.; Yanishevskaya, E.S.; Svetlov, A.V.; Goryachev, A.A. Functional activity of microorganisms in mining and processing of copper-nickel ores in the Murmansk Region. Proceedings of the Murmansk State Technical University. 2018, 21, 109-116. (In Russian).

101. Seleznev, S.G.; Boltyrov, V.B. Ecology of Mining-Generated Object "Allarechensky Deposit Dumps" (Pechenga District, Murmansk Region). Izvestija VUZov. Gorny Zhurnal. 2013, 7, 73-79. (In Russian).

102. Masloboev, V. A. Assessment of the environmental hazard of storage of the mining and processing waste of non-ferrous sulfide ores / V. A. Masloboev, S. G. Seleznev, D. V. Makarov, A. V. Svetlov // Problems of mining and a sustainable development strategy for Russia's regions (a case study of Voronezh Region): Editorial board: V. I. Danilov-Danilyan (Editor-in-Chief), Yu. A. Medovar, A. E. Silina, V. G. Khlebostroyev. — Voronezh: Elist - 2014. — Pp. 24-51. [In Russian].

103. Watling, H. R. Simulated heap leaching and recovery of multiple elements from a mineralised black shale / H. R. Watling, D. M Collinsona., R. J. Watling, D. W. Shiers // Hydrometallurgy, - 2017. - № 167. - P. 48-57.

104. Makarov, D. V. Theoretical and experimental substantiation of the chemical transformations of sulfides in industrial wastes and a study of the effect of mineral oxidation products on their technological properties and the environment. Doctor of Engineering Thesis: 25.00.13, 25.00.36 / Makarov D. V. — Moscow, 2006. — 338 p. [In Russian].

105. Mining and metallurgical waste register of Murmansk region (as of 01.01.99) / Compiled by: Kozyrev A.A., Kalashnik A.I., Vishnyakov I.A. et al. - MurmanskApatity, 1999. — 96 p. [In Russian].

106. Svetlov, A.V. A feasibility study of heap leaching of non-ferrous metals from sulfide naturally-occurring and anthropogenic mineral resources of Murmansk Region / A.V. Svetlov, E.A. Kravchenko, E.A. Selivanova, S.G. Seleznev, D.V. Makarov, V.A. Masloboev // Industrial Ecology. — 2015. — No. 3. — Pp. 65-70. [In Russian].

107. Makarov, D. V. A study of the environmental hazard of and the potential for the recovery of valuable components from the granular slags of the Pechenganickel operation, Kola MMC / D. V. Makarov, D. S. Potapov, S. S. Potapov, A. V. Svetlov // Industrial Ecology. - 2013. — No. 82. - Pp. 54-58. [In Russian].

108. Voitekhovich, V. S. Report "Prospecting project for platinum group metals in Monchegorsk District (Monchegorsk and Monchetundry massifs)" / V. S. Voitekhovich, G. F. Bakaev, V. S. Mityugov, P. S. Davydov, T. L. Grokhovskaya et al. Monchegorsk: TsKE, 1999. 279 p. [In Russian]. 
109. Neradovsky, Yu. N. The structure and composition of the Pechenga slags: scanning electron microscopy studies / Yu. N. Neradovsky, E. E. Savchenko, N. N. Grishin, A. G. Kasikov, E. A. Okorochkova // 6th Russian National Fersman Scientific Conference. Apatity - 2009. — Pp. 283-286. [In Russian].

110. Busyrev V. M., Churkin O. E. An estimate of the value of the reserves and a development feasibility study of anthropogenic deposits // Mining Information and Analysis Bulletin (science and technology journal). 2016. No. 6. Pp. $106-114$. [In Russian].

111. Likhacheva S.V., Neradovsky Yu.N. Concerning the classification of intergrowths of sulfide minerals in the Pechenga disseminated ores / Proceedings of the international meeting "Innovative processes for integrated and deep processing of minerals." Plaksinsky Readings 2013. - Tomsk. — Pp. 64-67. [In Russian].

112. Denisova Yu.L., Svetlov A.V. Copper-nickel ore concentration tailings of Kola MMC and potential applications // Transactions of the Kola Research Center of RAS. 2018. Vol. 9. No. 2. Pp. 821-824. [In Russian].

113. Chernousenko E.V., Mitrofanova G.V., Kameneva Yu.S., Vishnyakova I.N. An assessment of the action of complexing agents in the flotation of copper-nickel ores // Non-Ferrous Metals. 2019. No. 1. Pp. 7-12. [In Russian].

114. Potapov, S. S. Mineralogical and geochemical features of copper-nickel granular slag after electropulsed crushing. Methodological approaches to improve the concentration performance of slag as a potential anthropogenic mineral resource / S. S. Potapov, D. V. Makarov, A. V. Svetlov, D. S. Potapov, Yu. V. Erokhin, A. S. Potokin // "Modern methods for the integrated and deep processing of refractory mineral feeds" (Plaksinsky Readings 2015). - 2015. — Pp. 420-422. [in Russian].

115. Usov, A. F. Electric pulse disaggregation of materials - Russian experience / A. F. Usov, A. C. Potokin // IMPC. 2012. - № 2. - P. 05618-05626.

116. The basics of the mineralogy of hypergenesis: textbook / L.K. Yakhontova, V.P. Zvereva. Vladivostok: — Dalnauka, 2000. — 331 p. [In Russian].

117. Rylnikova, M.V. Pilot testing of a technology for the leaching of copper-pyrite ore processing waste / M.V. Rylnikova, D.N. Radchenko, A.F. Ilimbetov, A.N. Zvyagintsev // GIAB MGGU. — 2008. — No. 2. — Pp. 293-301. [In Russian].

118. Masloboev, V. A. Geoecological validation of mechanisms and parameters of physical-chemical processes facilitating the in-depth processing of complex suphide ores and mining wastes / V. A. Masloboev, D. V. Makarov, D. P. Nesterov, S. I. Mazukhina, I. V. Bocharova, Yu. P. Menshikov, A. V. Svetlov // Proceeding of the Murmansk State Technical University. - 2012. - V.15. N2. - P. 361-368. 


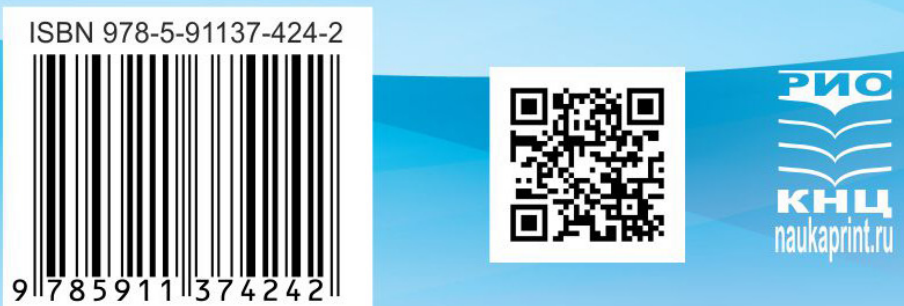

